\title{
Dopamine Receptors and Neurodegeneration
}

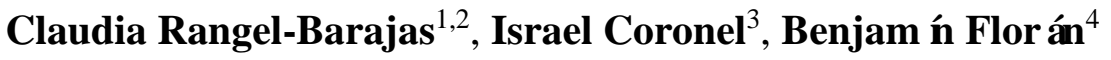

\author{
${ }^{1}$ Department of Psychological and Brain Sciences Program in Neurosciences, Indiana University Bloomington, \\ Bloomington, IN 47405, USA \\ ${ }^{2}$ Department of Pharmacology and Neuroscience, University of North Texas Health Science Center, Fort Worth, \\ TX 76107, USA. \\ ${ }^{3}$ Health Sciences Faculty, Anahuac University, Mexico Norte, State of Mexico, Mexico. \\ ${ }^{4}$ Department of Physiology, Biophysics and Neurosciences CINVESTAV-IPN, Mexico.
}

[Received November 16, 2014; Revised March 30, 2015; Accepted March 30, 2015]

\begin{abstract}
Dopamine (DA) is one of the major neurotransmitters and participates in a number of functions such as motor coordination, emotions, memory, reward mechanism, neuroendocrine regulation etc. DA exerts its effects through five DA receptors that are subdivided in 2 families: D1-like DA receptors $\left(D_{1}\right.$ and $\left.D_{5}\right)$ and the $D_{2}$-like $\left(D_{2}, D_{3}\right.$ and $\left.D_{4}\right)$. All $D_{A}$ receptors are widely expressed in the central nervous system (CNS) and play an important role in not only in physiological conditions but also pathological scenarios. Abnormalities in the DAergic system and its receptors in the basal ganglia structures are the basis Parkinson's disease (PD), however DA also participates in other neurodegenerative disorders such as Huntington disease (HD) and multiple sclerosis (MS). Under pathological conditions reorganization of DAergic system has been observed and most of the times, those changes occur as a mechanism of compensation, but in some cases contributes to worsening the alterations. Here we review the changes that occur on DA transmission and DA receptors (DARs) at both levels expression and signals transduction pathways as a result of neurotoxicity, inflammation and in neurodegenerative processes. The better understanding of the role of DA receptors in neuropathological conditions is crucial for development of novel therapeutic approaches to treat alterations related to neurodegenerative diseases.
\end{abstract}

Key words: Dopamine receptors, neurotoxicity, neurodegeneration, Parkinson's disease

Dopamine (DA) is a catecholamine neurotransmitter widely distributed in the central nervous system (CNS) and some peripheral areas including cardiovascular and renal system. In the brain, DA is involved in control of the movements, cognition, emotions, memory, reward mechanism and the regulation of prolactin secretion by the pituitary. Several diseases have been related with disturbances of DA transmission like neuropsychiatric disorders, such as attention deficit hyperactivity disorder (ADHD), Tourette Syndrome (TS), schizophrenia, psychosis, depression, etc., and with neurodegenerative diseases like Parkinson's disease (PD), Huntington disease (HD), multiple sclerosis (MS). Here, we will focus on the role of dopamine receptors and changes in their signal transduction pathways in neurodegenerative diseases.

Historically, the importance of the DAergic system in the brain was pointed out due to the investigation of $\mathrm{PD}$, which is the result of degeneration of the DAergic neurons of substantia nigra pars compacta $(\mathrm{SNc})$. There are three main sources of DA in the CNS: the nigrostriatal pathway, the mesocorticolimbic pathway and the tuberoinfundibular pathway, all of them involved in different neurophysiological features.

*Correspondence should be addressed to: Claudia Rangel-Barajas, Ph.D., Psychological and Brain Sciences Neurosciences Program, Bloomington Indiana University, Bloomington, IN, USA. Email: crangelb@indiana.edu 


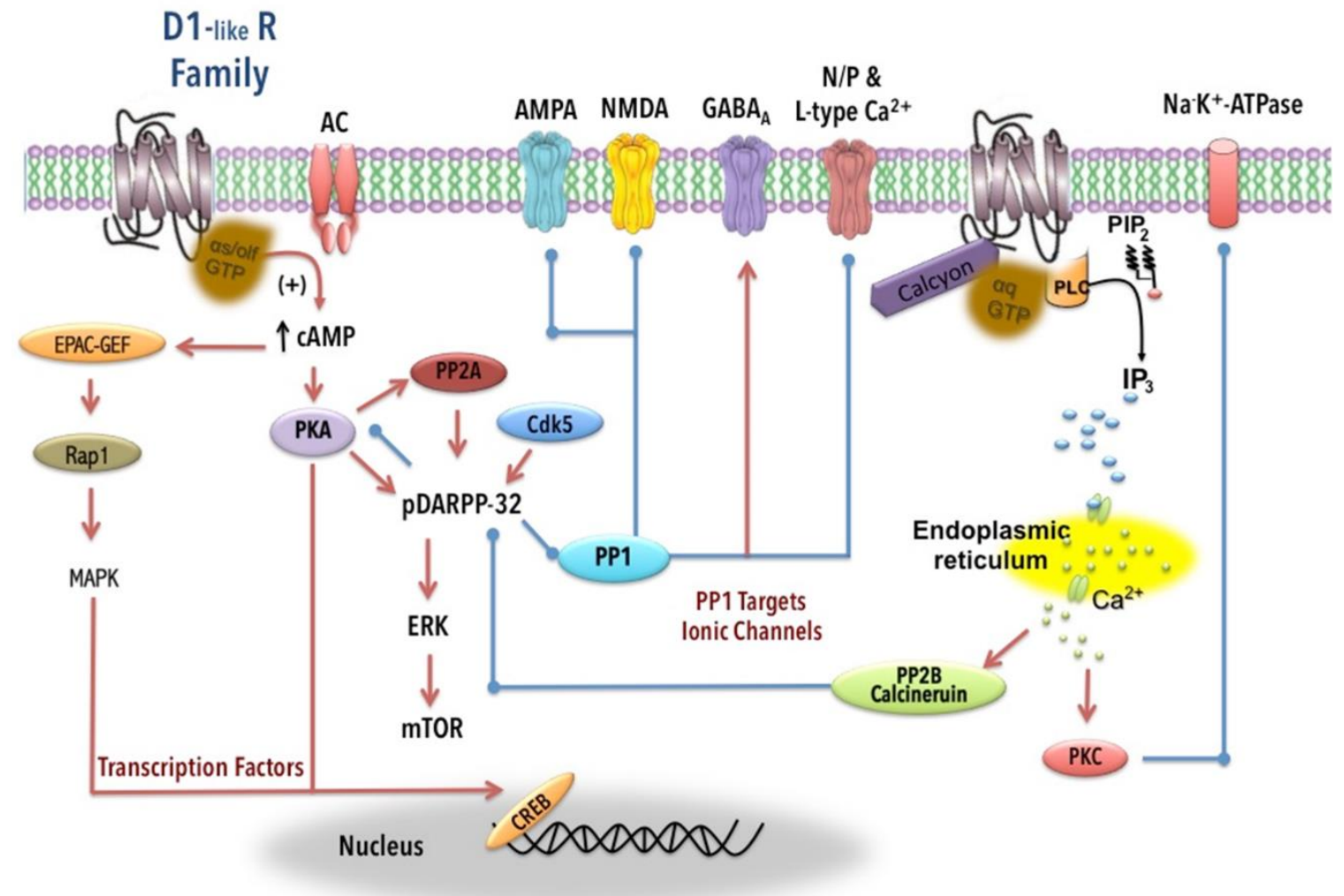

Figure 1. The D1-like DA Receptors Intracellular Signal Pathways. Shows the DA mediated effects through D1-like DA receptors that by the activation of intracellular signals. Stimulatory effects are indicated with red arrows and inhibitory effects in blue line ended with a circle. cAMP, 3'-5'-cyclic adenosine monophosphate; $\alpha_{\mathrm{s} / \text { olf }}$ or $\alpha_{\mathrm{q}}$ ATP, active $\mathrm{G} \alpha$ protein; PKA, protein kinase A; DARPP-32, dopamine and cyclic AMP-regulated phosphoprotein, $32 \mathrm{kDa}$; AC, adenylyl cyclase; PP1, PP2A or PP2B, protein-phosphatase 1, 2A or 2B; PKC, protein kinase C; PLC, phospholipase C; $\mathrm{IP}_{3}$, inositol triphosphate; mTOR, mammalian target of rapamycin; PIP2, phosphatidylinositol 2; $\mathrm{Ca}^{2+}$, calcium; MAPK, mitogen-activated protein kinase EPAC-GEF, guanine-nucleotide-exchange factor of Rap1; Rap1, Ras proximate 1. AMPA, $\alpha$-Amino-3-hydroxy-5-methyl-4-isoxazolepropionic acid receptors; NMDA, N-methyl-D-aspartate; GABA $\mathrm{A}_{\mathrm{A}} \gamma$ Aminobutyric acid A; CREB; cAMP response element-binding protein.

The nigrostriatal pathway is related with motor function, the SNc send its projections to the dorsal striatum and regulates through DA release and its receptors the activity of the basal ganglia networks, the coordinated movements is the result of the balance of the basal ganglia circuitry. In the mesocorticolimbic pathway the ventral tegmental area (VTA) projects to the ventral striatum or nucleus accumbens (Nacc), amygdala, olfactory bulb, hippocampus, cingulate gyrus and orbital and medial prefrontal cortex, this pathway is related with the cognitive function, motivation and emotion. Finally the tuberoinfundibular pathway where, the arcuate nucleus of the hypothalamus projects to the anterior pituitary delivering dopamine and controlling neuroendocrine functions such as the secretion of prolactin $[1,2]$.
The physiological effects of DA are mediated by dopaminergic receptors, which have widespread expression throughout the brain. In fact DA receptors are the main target of several drugs such as psychostimulants and antipsychotics. Interestingly DA receptors expression and intracellular signal transduction pathways, change during degenerative process and neurotoxicity worsening the symptoms and/or progression.

\section{Dopamine and Receptors Function}

The DA receptors (DARs) belong to the $\mathrm{G}$ protein coupled receptors family (GPCRs). There are five subtypes of mammalian DARs that are divided in two families according their structure and biological response. The D1like family includes $D_{1}$ and $D_{5} D A$ receptors $\left(D_{1} R\right.$ and 
$D_{5} R$ ), while D2-like DARs family consist of $D_{2}, D_{3}$ and $D_{4}$ receptors $\left(D_{2} R, D_{3} R\right.$ and $\left.D_{4} R\right)$.

Typically the D1-like dopamine receptors family (D1Rs) are positively coupled to adenylyl cyclase (AC) inducing the intracellular cyclic 3,5 adeninemonophosphate (cAMP) accumulation and the activation of the protein kinase dependent of cAMP (PKA) (Fig. 1), in contrast the D2-like dopamine receptors family (D2Rs) are negatively coupled to $\mathrm{AC}$, as a result their activation decreases the cAMP accumulation [3, 4] (Fig. 2), modulating the activity of PKA and its effectors [5]. However growing evidence has shown that activation of DARs is not only restricted to the AC modulation but also other signal pathways and might act differently depending of the brain area, physiological and/or pathological conditions that we will discuss further.

\section{D1-like Dopamine Receptors Expression and Signal Transduction Pathways}

The $\mathrm{D}_{1} \mathrm{Rs}$ share $80 \%$ in the amino acid sequence homology with $\mathrm{D}_{5} \mathrm{Rs}$ in the transmembrane domains [6, 7], this family of receptors is widely expressed in the brain, with higher densities in striatum or caudo-putamen, Nacc, substantia nigra pars reticulata $(\mathrm{SNr})$ and olfactory bulb [8]. Moderated expression in the entopeduncular nucleus, cerebral aqueduct and ventricles [9] and lower densities has been reported in the dorsolateral prefrontal cortex, cingulate cortex and hippocampus [10,11], D1Rs play an important role in locomotor activity, reward systems, learning and memory [12].

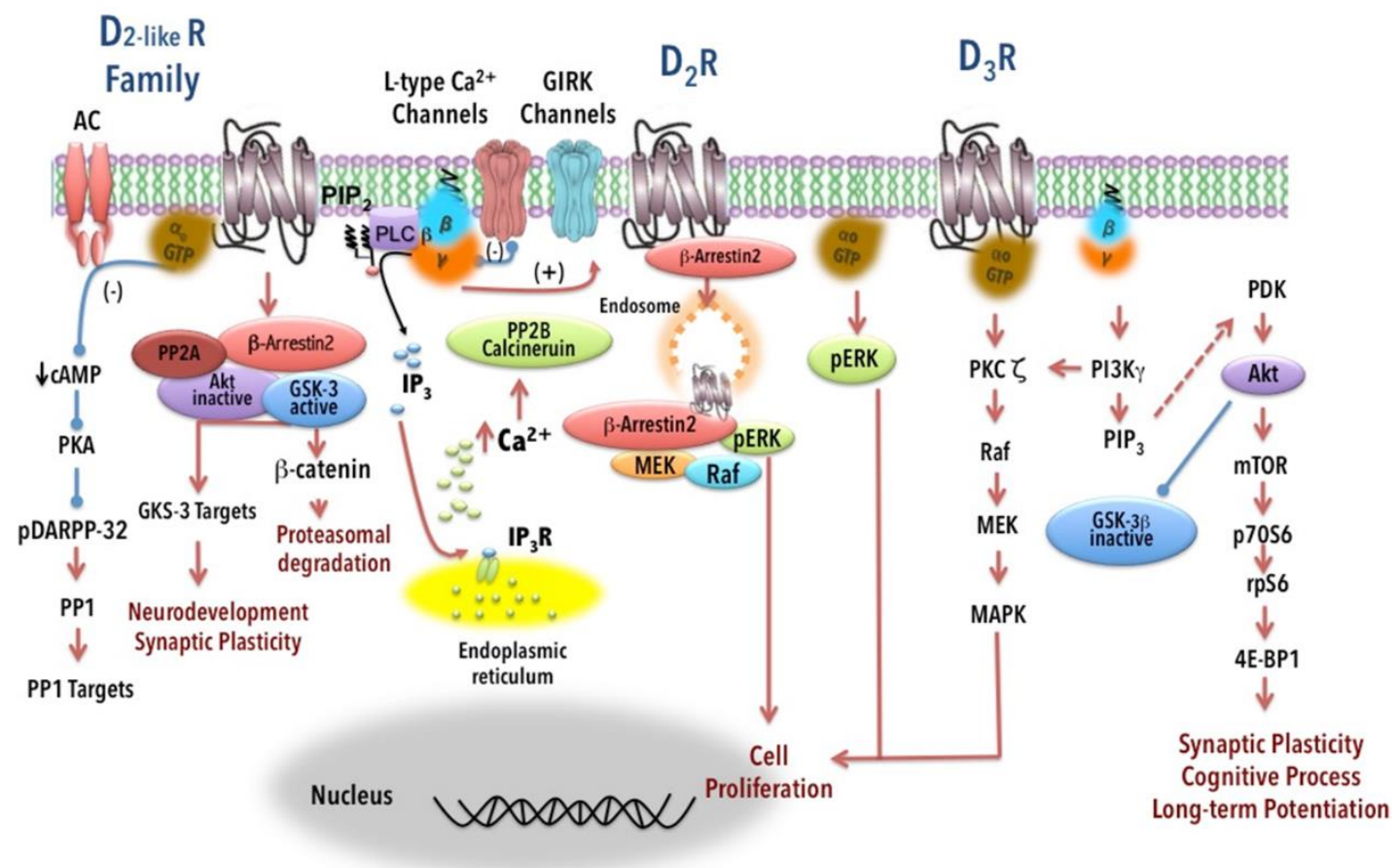

Figure 2. The D2-like DA Receptors Intracellular Signal Pathways. Shows the DA mediated effects through D2-like DA receptors that occur by a complex activation of intracellular signals that are related with events such as neurodevelopment, proteasomal degradation, cell proliferation and cognitive process. Stimulatory effects are indicated with red arrows, dashed red arrow indicates plausible activation and inhibitory effects in blue line ended with a circle. cAMP, 3'-5'-cyclic adenosine monophosphate; $\alpha_{i} / o$ ATP, active $\mathrm{G} \alpha_{\mathrm{i} / \mathrm{o}}$ protein; PKA, protein kinase A; DARPP-32, dopamine and cyclic AMP-regulated phosphoprotein, $32 \mathrm{kDa}$; AC, adenylyl cyclase; PP1, PP2A or PP2B, protein-phosphatase 1, 2A or 2B; MAPK, mitogen-activated protein kinase; PKC, protein kinase C; Akt, thymoma viral proto-oncogene; GSK-3, Glycogen Synthase Kinase-3; PLC $\beta$, phospholipase C isoform $\beta$; PI3K, phosphatidylinositol 3-kinase; PIP2, PIP3, phosphatidylinositol 2 and 3; $\mathrm{IP}_{3}$, inositol triphosphate; $\mathrm{Ca}^{2+}$, calcium ; GIRK, G protein coupled inward rectifier potassium; MEK; Raf,; ERK, extracellular signal-regulated kinase protein kinase; PDK, phosphoinositide-dependant kinase; mTOR, mammalian target of rapamycin; p70S6, p70S6 kinase; rpS6, ribosomal S6 protein; 4E-BP, eukaryotic initiation factor 4E-binding protein 1. 
Typically D1Rs induces the activation of the AC through the direct activation of guanosine nucleotidebinding proteins (G-proteins), the subunit $\mathrm{G}_{\mathrm{s} / \mathrm{olf}}$ of $\mathrm{G}$ proteins binds to the catalytic subunit $\mathrm{C}_{2}$ of the enzyme inducing the interaction between the subunits $\mathrm{C}_{1}-\mathrm{C}_{2}$ of the $\mathrm{AC}$ which in turn, induces the conversion of adenosine triphosphate (ATP) into cAMP [13, 14]. The cAMP interacts with the regulatory subunits of PKA inducing the release of the catalytic subunits that phosphorylate different substrates $[15,16]$. One of the most studied proteins involved in the regulation of signal transduction pathway mediated by DARs and PKA is the Dopamine and cAMP-regulated phosphor-protein, $32 \mathrm{kDa}$ (DARPP32). In fact dopamine receptors co-localize with DARPP32 in several brain regions [17]. The phosphorylation of DARPP-32 by the PKA in the threonine-34 residue induces the inhibition of the protein phosphatase-1 (PP1) [18], while the phosphorylation of the residue threonine75 of DARPP-32 by cyclin-dependent kinanse 5 (Cdk5) induces the inhibition of PKA $[19,20]$ causing a feedback loop in the activation of the PKA (Fig. 1). The activation of the PKA same as the inhibition of PP1 mediated by PKA, may cause directly changes in the phosphorylation state of several channels such as $\alpha$-Amino-3-hydroxy-5methyl-4-isoxazole-propionic acid receptors (AMPA), Gamma Aminobutyric Acid channel A $\left(\mathrm{GABA}_{\mathrm{A}}\right), \mathrm{N}-$

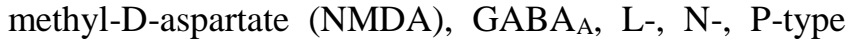
$\mathrm{Ca}^{2+}$ that play an important role in the electrical properties of the neurons [21, 22, 23, 5, 24], the PKA directly or through DARPP-32 can also regulates extracellular signal regulated kinases 1 and 2 (ERK 1/2) involved in the changes in the protein transcription, this pathways has been related with pathological conditions in PD [25].

D1Rs may elicit an alternate cAMP signaling pathway non-dependent of PKA [20]. The cAMP can activate through the Ras superfamily guanine nucleotide exchange factors (GEFs), which are activators of Ras and Ras-like small G-proteins, specifically has been shown activates Ras-proximate 1 (Rap1) [26] that has been involved in cell polarity and migration [27; 28], Rap1 can also activate MAPK signaling implicated in the phosphorylation of transcription factors such as cAMP response element binding protein (CREB) that is involved in the increased or decreased transcription of genes [29].

D1Rs family also activates a signal transduction pathway that has been related with various neuropsychiatric disorders, activating the phospholipase $\mathrm{C}$ (PLC), mediated by a single transmembrane protein calcyon, which promotes the D1Rs interaction with $\mathrm{G} \alpha_{\mathrm{q}}$ instead $\mathrm{G} \alpha_{\text {s/olf }}$ [30], as a result PLC is activated and increases the accumulation of inositol triphosphate $\left(\mathrm{IP}_{3}\right)$ which in turn binds to the $\mathrm{IP}_{3}$ receptors from the intracellular compartments inducing intracellular $\mathrm{Ca}^{2+}$ release (Fig.1). $\mathrm{Ca}^{2+}$ plays an important role not only in signaling pathways causing the activation of proteins such as protein kinase calcium-dependent (PKC) but also in the modulation of neurotransmitters release by exocytosis. It has been shown that this particular signaling pathways occurs primary in the prefrotal cortex and calcyon has been found co-localize with D1Rs in the dendritic spines on the pyramidal neurons [31]. The activation of this pathway in the medial prefrontal cortex is involved in impulsive choice in rats and neuropsychiatric disorders [32], in fact up-regulation of the interaction of calcyon and D1Rs has been found in schizophrenic patients [33]. The activation of D1Rs is also related with regulation of electrochemical gradient through $\mathrm{Na}^{+} \mathrm{K}^{+}$-ATPase, which pumps the sodium out and the potassium into del cells. It's been shown that the activation of D1Rs inhibit the $\mathrm{Na}^{+} \mathrm{K}^{+}-$ ATPase through PKA and PKC signaling pathways in striatum [34, 35] (Fig. 1), it's also been shown that D1Rs are related with sodium homeostasis in the kidney $[7,36]$, where D1Rs might play an important role in nephropathy that we will briefly discuss later.

\section{D2-like Dopamine Receptors Expression and Signal Transduction Pathways}

The D2-like dopamine receptors family as we mentioned before, consists of $\mathrm{D}_{2}, \mathrm{D}_{3}$ and $\mathrm{D}_{4}$ DARs. For $\mathrm{D}_{2}$ Rs subtype additionally there are 2 isoforms the $\mathrm{D}_{2 \text {-short }}$ and $\mathrm{D}_{2 \text {-long. }}$. The $\mathrm{D}_{2} \mathrm{Rs}$ share $75 \%$ homology in the transmembrane regions with $\mathrm{D}_{3} \mathrm{Rs}$, while $53 \%$ identity with $\mathrm{D}_{4} \mathrm{Rs}$ [7]. The D2Rs are mainly expressed in striatum, external globus pallidus (GPe), core of Nacc, amygdala, cerebral cortex, hippocampus and pituitary. D2Rs mRNA also found in the temporal and enthorinal cortex and in the septal region as well in the VTA and SNc in the dopaminergic neurons $[2,7]$.

The activation of this family of receptors typically leads to the inhibition of AC activity [37, 1], as well inhibition of PKA and DARPP-32 [38], however slight but complex differences in the functional response and activation of signaling pathways have been observed in receptors from this family, specially for $\mathrm{D}_{3}$ Rs subtype (Fig. 2). For example it has been shown that $\mathrm{D}_{2} \mathrm{Rs}$ induces a strong inhibition of forskolin-induced cAMP accumulation in HEK-293 cells, while stimulation of $\mathrm{D}_{3}$ Rs expressed in transfected HEK-293 cells showed either low or not inhibitory effect on AC activity [39, 40], however when $D_{3} R s$ were expressed in a human neuroblastoma cell line, the effects were consistent with HEK-293 cells [41]. Discrepancies could be due to a differential expression of the $\mathrm{AC}$ isoforms, because $\mathrm{D}_{3} \mathrm{Rs}$ were able to inhibit the AC activity when were cotransfected with the $\mathrm{AC}$ isoform $\mathrm{V}$ (ACV) but not with isoform VI [42]. Furthermore the ACV is widely expressed in dopaminergic-innervated brain regions 
especially in the striatum [43, 44] and it has been suggested that this particular isoform also plays an important role in anxiety, depression, abuse drug withdrawal and L-3,4-dihydroxyphenylalanine L-DOPA induced dyskinesia (LID) [45-47].

D2Rs also modulate G-protein-coupled inward rectifier potassium (GIRK) channels (Fig. 2), which mediate neuronal electrical response [48], through GPCRs coupled to $\mathrm{G \alpha}_{\mathrm{i} / \mathrm{o}}$ protein and also varying the effects between the receptors of this family, the effect seems to be through the $\beta \gamma$ subunits for $D_{2} R s$ and $D_{4} R s$ but not $\mathrm{D}_{3} \mathrm{Rs}$ [49]. Furthermore it has been shown in $\mathrm{D}_{2} \mathrm{Rs}$ knockout mice that $\mathrm{D}_{2}$ Rs but not $\mathrm{D}_{3}$ Rs couple to GIRK channel in the substantia nigra neurons [50].

It's been reported that D2Rs are also able to activate cell proliferation-related pathways such as Mitogenactivated protein kinase (MAPK) signaling. The activation of ERK1/2 has been also observed in a variety of cell lines, including in HEK-293 cells, COS-7 cells and C6 glioma cells, for this signaling pathway, $\mathrm{D}_{2} \mathrm{Rs}$ and $\mathrm{D}_{4} \mathrm{Rs}$ also display some differences in the intensity of ERK/MAPK activation compared to $\mathrm{D}_{3}$ Rs using highly selective compounds [51, 52]. On the other hand, the complex GPCRs- $\beta$-arrestin also activates ERK/MAPK once the receptor is internalized [53]. Recently it was demonstrated that the complex $\mathrm{D}_{2}$ Rs- $\beta$-arrestin can activate ERK but this effect was not observed in $D_{3} R s$. However in the same conditions was found that ERK could be activated by $\mathrm{D}_{3}$ Rs in HEK-293 and COS-7 cell lines only when $\mathrm{G} \alpha_{o}$ is co-expressed but not $\mathrm{G} \alpha_{\mathrm{i}}$, while $\mathrm{D}_{2} \mathrm{Rs}$ can mediate the ERK activation by both isoforms $\mathrm{G}_{\mathrm{i} / \mathrm{o}}$ proteins and by $\mathrm{D}_{2} \mathrm{R}-\beta$-arrestin complex (Fig. 2) [54]. MAPK signaling is activated by $\mathrm{D}_{4} \mathrm{Rs}$ and we recently reported that the $\mathrm{D}_{2 \text {-short }}-\mathrm{D}_{4} \mathrm{Rs}$ form functional heteromer inducing phosphorylation of ERK1/2, interestingly, this interaction was disrupted when the polymorphic variant $\mathrm{D}_{4.7}$ was used, which has been associated ADHD [55].

Stimulation of D2-like receptors activates the Akt (thymoma viral proto-oncogene also knows as protein kinase $\mathrm{B} \mathrm{PKB})$ signaling $[56,57]$. In vivo it has been shown activation of Akt in striatum and Nacc after the D2like agonist administration [56]. The effect of $\mathrm{D}_{3}$ Rs has also been studied in vivo and in vitro. In vivo $\mathrm{D}_{3} \mathrm{Rs}$ knock out mice showed that these receptors participates in Akt phosphorylation [58]. In vitro $\mathrm{D}_{3} \mathrm{Rs}$ were able to increase $\mathrm{PKC}$ and PI3K activity [59]. Specific activation $\mathrm{D}_{3}$ Rs enhance the Akt activity, which has been associated to increased dendritic arborization in dopaminergic neurons from mouse embryos [60]. The activation of Akt regulates the activity of the mammalian target of rapamycin (mTOR) and consecutive targets related with synaptic plasticity and cognitive processing [61]. In contrast the inactivation of the Akt (by protein phosphatase 2A PP2A), turns in the activation of the two isoforms of Glycogen synthase kinase-3 (GKS-3 $\alpha / \beta)$. The GSK-3 is a protein kinase abundantly expressed in brain and is involved in signal transduction cascades relevant to neurodevelopment [62] and also regulates proteasome degradation through $\beta$-catenin [63], which involved in neurodegenerative and psychiatric conditions such as HD, bipolar disorder and schizophrenia [64]. A recent study showed that $\mathrm{D}_{3} \mathrm{Rs}$ activates Akt, which in parallel activates, mTOR/p70S6/4E-BP1 signaling, probably mediated by phosphoinositide dependent kinase (PKD) and also causes the inactivation of GSK-3 by Aktdependent phosphorylation (Fig. 2), in medium-sized spiny neurons (MSNs) of striatum and Nacc [65], pathways that have been related with synaptic plasticity, cognitive process, long-term potentiation (LTP) and longterm depression (LDP) [61]. $\mathrm{D}_{3} \mathrm{Rs}$ also induced the activation of phosphatidylinositol 3-kinase (PI3K) and the atypical protein kinase $\mathrm{C}(\mathrm{PKC} \zeta)$ this effect is apparently mediated by $\beta \gamma$ subunit of G-proteins and activates MAPK signaling [51]. Signaling pathways might occur differently in specific brain regions and more important in pathological conditions. We will further discuss the specific changes of signal transduction pathways in neurotoxicity and neurodegenerative diseases.

\section{Dopamine and Dopamine Receptors in Neurotoxicity}

At physiological concentrations DA do not exhibits toxicity, however malfunction on DA release and/or metabolism could lead neurotoxicity. Mechanisms still unclear, but several evidences have shown that is caused by oxidative stress, neuroinflamation and apoptosis. For example, it have been shown that cortical, striatal, mesencephalic cells displayed toxicity by DA treatment [66-68]. DA-induced toxicity was initiated by the interaction with mitochondrial oxidative phosphorylation system causing inhibition of Complex I and decreasing ATP (Fig. 3A) [69]. In vitro studies demonstrated that the application of DA induces death of striatal cells [70]. DA also activates apoptotic signaling through mechanisms of oxidation [71] and necrotic cell death [72]. The effects of DA in toxicity were for long time associated with quinones and reactive oxygen species (ROS) caused by the metabolism of DA [73, 74, 75]. However recent evidences have shown that angiotensin receptors and the renin-angiotensin system (RAS) are also involved in neurotoxicity (Fig. 3B) [76] and the DA receptors could be participating in this modulation. In renal tissue was described that $\mathrm{AT}_{1} \mathrm{Rs}$ enhances D1Rs signaling [77]. In the brain, D1Rs antagonist partially blocked the neurotoxicity induced by DA [78]. Here we will briefly discuss the role of DA and DARs in RAS-induced neurotoxicity by oxidative stress and inflammatory 
response but more detailed reviews have been published

$[74,76,79,80]$.

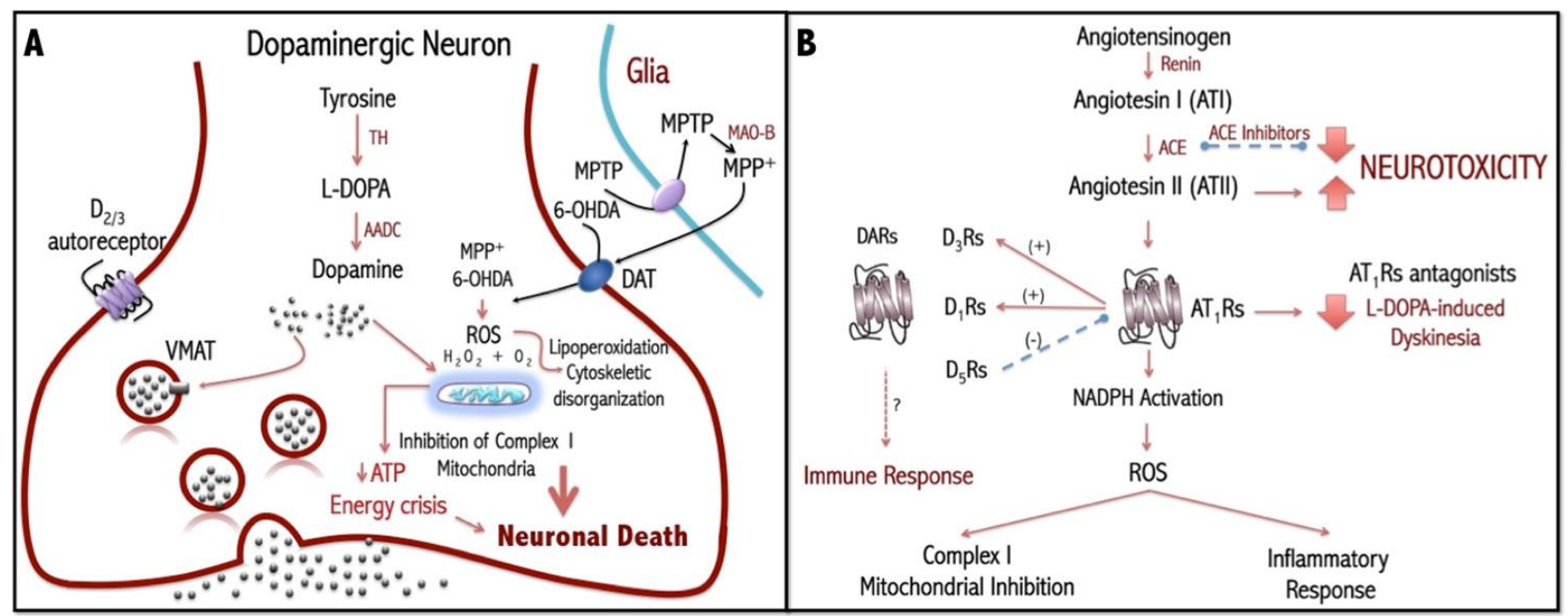

Figure 3. Oxidative stress and Neurotoxicity. A. Shows the neurotoxic mechanisms of DA and neurotoxins used to mimic PD in the dopaminergic neuron. DA and the neurotoxins 6-hydroxydopmine (6-OHDA) and 1-methyl-4-phenyl-1,2,3,6-tetrahydropyridine (MPTP), cause reactive species of oxygen (ROS) affecting the mitochondrial function and lipoperoxidation and cytoskeletal disorganization, which leads energy crisis and neuronal death. MPTP is first incorporated into the glial cells and metabolized to MPP ${ }^{+}$, this metabolite can cross the membrane through the DA transporter (DAT) to reach intracellular compartments in DAergic neuron, while 6-OHDA can directly cross through DAT. B. Neurotoxicity by renin-angiotensin system (RAS) activation and DA receptors. In RAS, angiotensinogen is converted to Angiotensin I (AI) by renin, AI is converted into Angiotensin II (AII) thought angiotensin converting enzyme (ACE), AII mediate their actions by angiotensin receptors $\mathrm{AT}_{1}$ and $\mathrm{AT}_{2} \mathrm{Rs}$. $\mathrm{AT}_{1}$ Rs activate the nicotidamine adenine dinucleotide phosphate oxidase complex (NADPH), which is the major source of ROS causing mitochondrial dysfunction and inflammatory response. The interaction $\mathrm{AT}_{1} \mathrm{Rs}$ with of $\mathrm{D}_{1}$ and $\mathrm{D}_{3} \mathrm{Rs}$ increases the $\mathrm{DA}$ response while $\mathrm{D}_{5} \mathrm{Rs}$ can regulate the $\mathrm{AT} \mathrm{R}_{1} \mathrm{~s}$ by proteasome mechanisms. DA receptors are also related with immune response in T cells.

\section{Oxidative Stress}

The oxidative stress is the result of the imbalance between ROS such as peroxides and free radicals and the ability of the biological system to detoxify them. ROS causes lipid peroxidation, cytoskeleton disorganization and DNA defects phenomena that convey in cell death and in this particular scenario on DAergic neurons; the DA autooxidation might increase ROS levels (Fig. 3A). In fact basal ROS levels are high in dopaminergic neurons. Indeed, normal enzymatic metabolism of DA induces the formation of hydrogen peroxide via monoamine oxidase activity [74]. It has been shown that DA oxidized metabolites inhibit the mitochondrial respiratory system by the inhibition of complex I and reduction of ATP causing energy crisis [69]. In fact neurotoxins used to experimentally model nigral degeneration in vitro as well as in vivo such as 6-hydroxydopamine (6-OHDA) and 1methyl-4-phenyl-1,2,3,6-tetrahydropyridine (MPTP) cause neurodegeneration mediated by both ROS and mitochondrial inhibition (Fig. 3A) [74]. However ROS is involved in a complex process of neurotoxic pathways where RAS and the nicotidamine adenine dinucleotide phosphate oxidase complex (NADPH) are also participating.

\section{Renin-Angiotensin System}

RAS influence and modulate the sodium balance, extracellular fluid volume in the kidney and systemic vascular resistance, which was initially considered only as a circulating humoral system that regulates blood pressure, sodium and water homeostasis [76]. The precursor in this system is the glycoprotein angiotensinogen, which is converted by renin and Angiotensin-Converting Enzyme (ACE) into Angiotensin II (AII) (Fig. 3B). The AII mediates its actions via two GPCRs, the Angiotensin II type 1 Receptor $\left(\mathrm{AT}_{1} \mathrm{Rs}\right)$ and Angiotensin II type 2 Receptor ( $\left.\mathrm{AT}_{2} \mathrm{Rs}\right)$ [81, 82]. The $\mathrm{AT}_{1} \mathrm{Rs}$ receptors mediate most of the classical peripheral actions of AII such as the induction systemic vasoconstriction, which leads to elevated peripheral 
resistance and ultimately increases blood pressure, while the function of the $\mathrm{AT}_{2} \mathrm{Rs}$ receptors remains more elusive and controversial. Although, it's generally considered that the AII by $\mathrm{AT}_{2} \mathrm{Rs}$ mediated responses exerts effects directly opposed to those mediated by $\mathrm{AT}_{1} \mathrm{Rs}$ [83], thereby antagonize many of their effects. Interestingly in the last years, all components of the classical RAS have been identified in different brain areas and inside the blood-brain barrier, this system has been involved in vulnerability to neurodegenerative diseases like Alzheimer's disease [84], MS [85] and PD [86] and it's also been reported to participate in alterations of memory process [87]. Furthermore, it has been described that brain levels of AII are higher than circulating levels [88], and that the precursor protein angiotensinogen is mainly produced by astrocytes [89] with lower levels in neurons [90]. The components involved in the effects of AII in peripheral tissues such as NADPH-oxidase have also been found in neurons [91] and glial cells [92, 93]. It has been demonstrated the presence of different cytoplasmic and membrane subunits of the NADPH complex in mesencephalic DAergic neurons, astrocytes and microglia [94, 95, 96]. NADPH-oxidase complex is the most significant source of ROS other that mitochondria [97]. As a matter of fact, the neuronal loss is reduced by inhibitors of NADPH-oxidase, which suggests that $\mathrm{NADPH}$ activation and NADPH-derived ROS are involved in the AII-enhanced DAergic neuronal death [98, 95, 96]. Impaired RAS has been reported especially in aging diseases [99]. For example, several studies have reported the presence of RAS components in the basal ganglia, particularly in the nigro-striatal system $[100,101$, 102, 103]. The $\mathrm{AT}_{1} \mathrm{Rs}$ and $\mathrm{AT}_{2} \mathrm{Rs}$ were found to be expressed in primary mesencephalic cell cultures [104, $95,96]$, in nigral DAergic neurons and glial cells in both rodents and primates [105] and it was shown that AII induces DA release, which is blocked by $\mathrm{AT}_{1} \mathrm{Rs}$ antagonists [106]. The interaction between the RAS and the DAergic system is particularly interesting, previous evidences suggested that DA and angiotensin systems directly counter-regulate each other in renal cells [107] and that abnormal counter-regulatory interactions between dopamine and AII play an important role in renal degeneration and hypertension [108]. In renal proximal tubule cells, evidences suggest functional interaction between several types of DA receptors and $\mathrm{AT}_{1} \mathrm{Rs}$ receptors, as well as dimerization of $\mathrm{AT}_{1} \mathrm{Rs}_{\mathrm{B}} \mathrm{D}_{1} \mathrm{Rs}$ inducing potentiation of $\mathrm{D}_{1} \mathrm{Rs}$ signaling [77]. For example $\mathrm{AT}_{1}$ Rs-D ${ }_{3}$ Rs aberrant interaction has been related with hypertension [109], the $\mathrm{AT}_{1} \mathrm{Rs}_{-} \mathrm{D}_{5}$ Rs interaction was also showed, where DA induces activation ubiquitinproteasome pathway for $\mathrm{AT}_{1} \mathrm{Rs}$ through $\mathrm{D}_{5} \mathrm{Rs}$ [108] (Fig 3B). In neurotoxin-induced parkinsonism with 6-OHDA and MPTP the role of RAS has been studied and evidences indicate that in these models up-regulated levels of AII, exacerbates the DAergic neuronal death mediated by $\mathrm{AT}_{1} \mathrm{Rs}$ [86]. Experimental data also support the involvement of brain RAS in dopaminergic degeneration $[110,111,112]$. It was demonstrated that AII increased the neurotoxic effect induced by low doses of 6-OHDA, and the treatment with inhibitors of ACE $[113,114,112]$ or blockage of $\mathrm{AT}_{1} \mathrm{Rs}[98,95,96]$ resulted in a significant reduction of both the loss of dopaminergic neurons and the levels of protein oxidation and lipid peroxidation induced by the neurotoxins [115]. Furthermore antagonist of $\mathrm{AT}_{1} \mathrm{Rs}$ has been shown to be neuroprotective [116].

Interaction between AII and DA was suggested by early microdialysis studies, which showed that acute AII perfusion induces DA release and the effect was blocked by $\mathrm{AT}_{1} \mathrm{Rs}$ antagonists [106, 117]. The mechanism responsible for the AII induced DA release has not been completely clarified, although it's been thought that involvement of $\mathrm{D}_{2}$ auto-receptors could be participating [106]. $\mathrm{AT}_{1}$ Rs antagonists were capable to inhibit the LID (Fig. 3B), which is the major complication of L-DOPA treatment in PD [118]. An important number of studies in peripheral tissues, a direct counter-regulatory interaction between $\mathrm{AT}_{1}$ Rs and $\mathrm{D}_{2} \mathrm{Rs}$ has been also demonstrated $[119,120]$. Furthermore pro-renin receptors were found expressed in the nigral DAergic neurons and microglial cells in humans, monkeys and rats [121, 105]. Moreover, the pro-renin, $\mathrm{AT}_{1} \mathrm{Rs}$ and $\mathrm{AT}_{2} \mathrm{Rs}$ have been located intracellular compartments in DAergic neurons and glial cells [105]. These observations suggest the existence of an intracellular and intracrine RAS in dopaminergic neurons and functional interaction between DA receptors and AII receptors.

Interestingly, chronic inhibition of RAS by the use of ACE inhibitors resulted in increased dopamine levels, probably as a compensatory effect $[122,123]$, as a matter of fact, the ACE inhibitor peridonpril was beneficial in PD patients [123]. In addition chronic treatment with $\mathrm{AT}_{1} \mathrm{Rs}$ blockers such as candesartan do not change DA receptors expression, nor cause motor side effects and more importantly do not interfere with the beneficial effects of L-DOPA treatment [116], which is the most used therapy in PD. All these recent evidences together suggest that regulation of RAS and oxidative stress is a potential therapy in PD and LID.

\section{Neuroinflammation}

Neuroinflammation constitutes a fundamental process involved in the progression of several neurodegenerative disorders, such as PD, Alzheimer's disease, and MS. The neuroinflammation process includes activation of microglia, astrocytes and immune cells by inducing the 
release of inflammatory mediators such as cytokines, chemokines, neurotransmitters and oxidative stress, leading to neural cell death $[124,125,126]$. As mentioned before, the oxidative stress mediated by AII is also inducing inflammation. It has been shown that upregulation of local AII, induces oxidative stress and exacerbates inflammation $[127,128,80]$.

In addition to that, inflammation mediated by the activation of the immune system is also related to neurodegenerative diseases. Lately DA has been related with regulation of immune system. DA is present in immune cells and it's been shown that immune system cells can be regulated by DA receptors, which are expressed in the surface of T cells, B cells, neutrophils, eosinophils and monocytes [129]. Since immune cells have all the machinery molecules for DA synthesis, they are able to produce DA, which may act as autocrine/paracrine mediator on immune cells but also on neighboring cells $[130,131]$.

The DA receptors expression was found in leukocyte subpopulations where in T lymphocytes and monocytes showed low expression, neutrophils and eosinophils, moderate expression and B lymphocytes and natural killer (NK) cells had higher and more consistent expression for example, $D_{3} R s$ and $D_{5} R s$ were consistently in most of immune cells, while $\mathrm{D}_{2} \mathrm{Rs}$ and $\mathrm{D}_{4} \mathrm{Rs}$ had more variable expression, and $\mathrm{D}_{1} \mathrm{Rs}$ was not found [132]. DA exhibits different affinity for their receptors and it's been shown that depending of the concentration of DA is which receptor could be activated. For example activation of $D_{2} R s$ and $D_{3} R s$ induces polarization of the cluster of differentiation-4 $\left(\mathrm{CD}^{+} \mathrm{T}\right)$ cells and $\mathrm{D}_{1} \mathrm{Rs}$ antagonist caused the same effect [133]. The activation of $D_{5} R s$ increases the production of interleukins (IL) IL-23, cytokine that induces polarization of $\mathrm{CD}^{+} \mathrm{T}$ cells, which has been related with inflammatory response [134]. On the other hand activation of $\mathrm{D}_{2} \mathrm{Rs}$ and $\mathrm{D}_{3} \mathrm{Rs}$ in normal resting $\mathrm{T}$ cells induces production of IL-10 and tumor necrosis factor- $\alpha$ (TNF- $\alpha$ ) [135], while stimulation of $\mathrm{D}_{3} \mathrm{Rs}$ activates $\mathrm{CD}^{+}{ }^{+} \mathrm{T}$ cells inhibiting IL-4 and IL-10 synthesis [136].

Under pathological condition such as neurodegeneration or imbalance of homeostasis, inflammatory systems are active. Specialized patterns of adhesion of the cell surface during inflammation allow active $\mathrm{T}$ cells adhere to vessels and infiltrate to the brain, which contribute to neurodegenerative process $[137,138]$. In fact it has been shown that $\mathrm{D}_{3}$ Rs expression in $\mathrm{CD} 4^{+} \mathrm{T}$ cells is crucial for the destruction of DA neurons of the SNc in PD models and the $\mathrm{D}_{3}$ Rs knock out mice were resistant to MPTP [139], several evidences have shown that DA receptors expressed in immune cells play an important role in the autoimmune disorder MS.

\section{Alterations of Dopamine Receptors in Neurodegenerative Diseases}

\section{Parkinson's disease and $\mathrm{DA}$ receptors.}

PD is a neurodegenerative disorder characterized by the progressive loss of DAergic neurons of the SNc. The loss of dopamine has serious consequences in the balance of the pathways of the basal ganglia. According to the classic anatomical and functional basal ganglia models [140, 141], the lost of dopamine cause imbalance in the motor networks that stimulate and/or inhibit the initiation of movements. There are two main pathways in the basal ganglia, the direct pathway, primary associated with D1like dopamine receptors [142], where activation of D1Rs increases the GABA release in striato-nigral terminals [143] whereas, the indirect pathway mainly express D2like dopamine receptors [142] and their activation inhibit GABA release in striato-pallidal terminals [144, 145]. The adequate balance between the direct (stimulatory) and indirect (inhibitory) networks facilitates the execution of movements [141]. In PD, the lost of DAergic control leads to a hyperactivity of the inhibitory pathway, which induces bradykinesia, the main symptom of this disorder [146]. In addition pathological conditions occur when long lasting cellular modifications, especially if those have important influence in the response to dopaminergic receptors activation. For example, it has been shown that PD causes also reorganization in the level of expression of DA receptors, phenomena that has been called supersensitivity of DA receptors. Early evidence showed that DA receptors changes during $\mathrm{PD}$ using the hemiparkinsonian rat model induced by 6-OHDA, where the GABAergic medium-sized spiny neurons, which are most prominent neuronal phenotype in the striatum (95\%), showed increased mRNA coding for D2Rs in encephalin positive neurons which form the indirect pathway, while decreased mRNA coding for D1Rs were found in dynorphin/substance-P positive neurons that are related with the direct pathway of the basal ganglia [142], but not only the expression of the DA receptors is compromised in PD, it has been shown that also proteins and signaling transduction molecules are altered in this pathological condition probably as a compensatory effect to the supersensitivity [147]. The supersensitivity of DARs and signal molecules was further described in several structures of the basal ganglia such as in caudoputamen, striato-pallidal terminals and striato-nigral terminals [148-151].

The decreased expression of D1Rs in hemiparkinsonian animal models $[152,151]$ could explain in part one of the most important symptoms of this disease, the bradykinesia [153]. The most widely used pharmacological treatment for PD is L-DOPA, 
unfortunately chronic L-DOPA treatment causes several side effects, the most debilitating is the LID, which is characterized by the development of abnormal and involuntary movements. Alterations in D1Rs have been also related with this pathological condition. Despite the decreased expression of D1Rs, a increased signaling transduction pathway of D1Rs has been related with LID, no only in the striatum the input nuclei [25] but also in the $\mathrm{SNr}$, the output nuclei of the basal ganglia, where the expression of the ACV is increased as well the cAMP in the striato-nigral terminals and these changes were directly related with the development of dyskinesia and increased GABA release [47]. As described before, D1Rs activates the $\mathrm{AC}$, inducing cAMP accumulation and activation of PKA, which has several effectors and activation transcription factors, interestingly, it has been shown that effectors of PKA such as DARPP-32, ERK1/2 and mTOR are altered during LID in hemiparkinsonian mouse model [25, 154, 155], Cdk5 also is increased in LID using MPTP primate parkinsonian models (Fig. 1) [148]. However, in agreement to our findings, recent evidence showed that ACV might be critical for the development of dyskinesia since the silencing specific ACV silencing in the striatum attenuates LID [156].

With very good agreement is known that D2Rs in the indirect pathway of the basal ganglia also changes during dopaminergic denervation in opposite way. D2Rs are upregulated in pallido-nigral neurons [142]. Increased levels of mRNA coding for D2Rs were early showed [142, 148] and increased binding for D2Rs has been associated with PD, however no differences where found in LID of primate parkinsonian model induced by MPTP [148]. Furthermore the LID develops gradually over time and D2Rs, despite dopamine denervation increases the mRNA levels and protein, D2Rs are not further elevated in LID neither in animal models nor postmortem studies, as a matter of fact in PD patients L-DOPA normalizes the upregulation $[157,158]$. By then it was unclear whether or not the $D_{3} R s$ subtype was participating in the supersentitivity by dopamine denervation, however their low expression in striatum made focus the attention in $\mathrm{D}_{2} \operatorname{Rs}[159,160]$. In the last decade, $\mathrm{D}_{3}$ Rs attracted the attention, it's important to mention that the helical transmembrane spanning region (TMS) of $\mathrm{D}_{2} \mathrm{Rs}$ and $\mathrm{D}_{3} \mathrm{R}$ receptors share $75-80 \%$ homology in amino-acid sequence and the TMS is directly involved in the orthosteric-binding site, main reason why targeting $\mathrm{D}_{3} \mathrm{R}$ has been challenging, however $\mathrm{D}_{3}$ Rs-preferring compounds have been developed making possible the study of the role of $\mathrm{D}_{3}$ Rs in PD.

Despite the low abundance of $\mathrm{D}_{3}$ Rs are expressed in the direct pathway [21], we previously reported functional response in the GABAergic striato-nigral terminals [161], where presynaptic $\mathrm{D}_{3} \mathrm{Rs}$ are modulated by the calcium calmodulin kinase II $\alpha$ (CAMKII $\alpha)$ [162]. The mRNA codifying to $\mathrm{D}_{3}$ Rs remains unchanged during dopamine denervation [163]. However L-DOPA treatment induces a remarkable increase in dynorphin positive striatal neurons, which project to the $\mathrm{SNr}$ where $\mathrm{D}_{3} \mathrm{Rs}$ normally has moderate expression. Probably pathological conditions enhance their expression, according with that; recently it has been shown that $\mathrm{D}_{3}$ Rs are up-regulated in caudo-putamen and SNc in Lewy Body disease and Parkinson disease Dementia [164]. Recently the LID has been related to interactions between $\mathrm{D} 1-\mathrm{D}_{3} \mathrm{Rs}$ where CAMKII $\alpha$ might play an important role [165].

The role of $\mathrm{D}_{3} \mathrm{Rs}$ has been also studied in neurodegenerative process because it's been shown their importance in neuroprotection. For example, the stimulation of $\mathrm{D}_{3}$ Rs-preferring DA receptors agonist 7OH-DPAT promotes proliferation and possibly differentiation of dopaminergic neurons of the SNc in rats [166]. Chronic administration of 7-OH-DPAT was reported to restore the dopaminergic neurons in the nigrostriatal pathway in unilaterally lesioned rats treated with the neurotoxin 6-OHDA [167]. In addition to cell proliferation, the SNc neurons were reported to adopt a mature neuronal dopaminergic phenotype with projections arising from newly generated cells. These effects might be related to a mitogenic response elicited via $\mathrm{D}_{3} \mathrm{Rs}$ activation of receptors expressed on mesencephalic dopaminergic neurons, which then may release neurotrophic factors.

DA receptors still been the main target in PD through L-DOPA, however growing evidences have shown that DA receptors act differently in pathological conditions and some changes in the expression level and DA receptors interaction could lead a potential novel therapeutic targets. Interestingly several reports have shown that targeting $\mathrm{D}_{3}$ Rs reduces LID, in addition to that $\mathrm{D}_{3}$ Rs interact with D1Rs [168, 169] and enhances D1Rs stimulated GABA release in $\mathrm{SNr}$ [161], the functional effects and dynamic of this interaction seems to be mediated by CAMKII $\alpha$ [162] and could be involved in LID and other pathological conditions. All these recent evidences about the modulation of $\mathrm{D}_{3} \mathrm{Rs}$ over the $\mathrm{D}_{1} \mathrm{Rs}$ might lead to novel approaches to treat PD and LID, however further studies are needed to examine potential side effects when targeting $\mathrm{D}_{3} \mathrm{Rs}$ in this pathological conditions since $\mathrm{D}_{3}$ Rs exhibit a higher expression in other brain regions.

\section{Huntington disease and $\mathrm{DA}$ receptors.}

Huntington's disease is a dominant inherited neurodegenerative disease that is characterized by chorea (involuntary jerk movements), cognitive deficits and psychiatric disturbances such as agitation irritability and 
psychosis, symptoms progressively worsen until dead occurs. The cause is a mutation in the gene coding for hutingtin $(h t t)$ where it has been shown increased CAG repeats (glutamine), more than 35 repeats predispose to HD [170] and increased number of repeats is correlated with the HD onset [171]. The main histopathological feature is a profound lost of MSNs [172] in the striatum the input nuclei of the basal ganglia, however other structures are also affected such as, cerebral cortex, thalamus, hypothalamus and hippocampus but with less degree [173]. It has been suggested that the lost of MSNs neurons might be related to increased glutamatergic release from cortical and thalamic regions, which could be increasing the sensitivity of glutamate receptors [174, 175], but also glutamate transporter 1 (GLT1) might play an important role because it has been shown that the expression of GLT1 is reduced in HD [176], since GLT1 plays a critical role in glutamate removal by the astrocytes, excitotoxicity might occur. Alterations in DA transmission may also play a role, because it has been also shown that DA regulates the expression of GLT1 in striatal astrocytes [177], maybe the loss of the balance dopamine-glutamate contributes to the toxicity.

DA plays an important role in the motor and cognitive functions and is also known that DA can regulate glutamatergic cortical neurons [178]. Early studies reported extensive atrophy of the SNc [179], postmortem studies showed also decreased expression of tyrosine hydroxylase (TH) the limiting enzyme in the synthesis of DA [180] suggesting impairments of DA transmission in HD. In addition the DA transporters also showed alterations in the striatum, a decreased binding for the membrane DA transporter (DAT) and for the vesicular monoamine transporter 2 (VMAT2) probably due to the decrease in the dopaminergic striatal innervation [181, 182]. However other studies showed increased levels of DA in the nigro-striatal pathway in HD, according to that, the therapeutic agent to treat HD is tetrabenazine (TBZ). TBZ is a VMAT blocker and it's been shown to be beneficial to treat $\mathrm{HD}$, unfortunately $\mathrm{TBZ}$ is only helpful in the early stages of the disease and then becoming ineffective, interesting neurochemical studies have shown that increased DA occurs only in early stages of HD as well [183], where a significant decrease of striatal dopaminergic terminals was also reported [184].

The DA receptors also changes in HD, it has been shown that the binding for DARs is decreased in HD patients [185]. Similar results were showed in transgenic mice used as animal model of HD [186]. Positron emission tomography (PET) studies showed that DARs are decreased in striatal regions in both symptomatic and asymptomatic HD patients suggesting that DA alterations disrupts the expression level of the DARs in early stages
[187]. Furthermore the DA loss in pre-symptomatic HD patients was correlated with cognitive impairs [188].

In R6/2 HD model which is a HD transgenic mouse that has an aggressive disease onset and progression that shows motor abnormalities [189] and learning impairments [190], important loss of striatal neurons metenkephalin positive were reported but not in substance-P positive [186], under the basal ganglia network, the metenkephalin positive neurons express preferentially the D2Rs and projects to GPe, while the substance-P positive neurons primary express D1Rs and projects to $\mathrm{SNr}[142$, 191]. Consistent with other neurodegenerative situations related to dopamine, the DA receptors expression change. All the D2Rs family showed significant loss in striatum, while in the D1Rs family $D_{1}$ Rs showed a decreased expression in but not $\mathrm{D}_{5}$ Rs. However in similarity with $\mathrm{PD}$, despite the decrease in $\mathrm{D}_{1} \mathrm{Rs}$ increased cAMP was found [186]. Changes of dopamine receptors expression and signaling molecules have also been reported in HD patients [192]. Interestingly robust elevations in the cAMP accumulation and transduction pathways occurs when a decreased expression of D1Rs in neurodegenerative process $[193,194,151,47]$. As a matter of fact, $\mathrm{D}_{1}$ Rs can also regulate the excitatory postsynaptic potentials (EPSCs) in layer V pyramidal neurons of the prefrontal cortex [178]. D1Rs has been also related with motor alterations by the abnormal regulation of GABA release in the $\mathrm{SNr}$ during LID [47], and abnormal burst patterns in the $\mathrm{SNr}$ were found in 140 CAG knock in HD mouse model too, where increased bursting rates where found in the $\mathrm{SNr}$ compared with wild type littermates [195], suggesting that changes in the output nuclei could be involved in the motor alterations symptoms of HD.

D1Rs could also play a role in progression of the disease. For example the activation of D1Rs receptors using agonists showed to accelerates the formation of $h t t$ nuclear aggregates, and it was found that the direct activation of AC using forskolin, mimic the effect and the response seems to be related with transcription factors, suggesting that the signal transduction pathway is involved in the aggregation of $h t t$ [42].

On the other hand GSK-3 $\beta$ also might participate in the neurodegenerative process of HD. As mentioned GSK- $3 \beta$ is a very promiscuous kinase that phosphorylate several substrates and is involved in many aspects of cell biology (Fig. 2), such as energy metabolism, microtubule stability and inflammation [196]. It's been known that an important factor in HD is changes in energy metabolism, htt-expressing cells showed important reduction of adenosine triphosphate (ATP) [197]. Recent studies showed a $50 \%$ reduction of GSK-3 $\beta$ in the frontal cortex in brain from HD patients and this also occurred in R6/1 mice model, suggesting this could be related with the 
cognitive alterations [197]. It's been shown that the GSK$3 \beta$ is increased in lipid rafts of knock-in HD mice brains and inhibitors of GSK-3 $\beta$ significantly reduced the neuronal dead in $h t t$ expressing neuronal culture cells [198], however since GSK-3 has an important number of substrates, the inhibition as a therapeutic approach has to be considered with caution, but a possibility could be pharmacological modulation mediated by receptors. Interestingly $\mathrm{D}_{2} \mathrm{Rs}$ and $\mathrm{D}_{3} \mathrm{Rs}$ knock-out mice display enhanced striatal Akt activation [199], and in HD transgenic model a profound loss of these receptors was found [186]. In addition, atypical antipsychotics used to manage psychiatric alterations in HD, have been shown to antagonize $\quad D_{2} R / \beta$-arrestin2 interactions more efficaciously than G-protein-dependent signaling (Fig. 2), whereas typical antipsychotics inhibit both pathways with similar efficacy [200]. GSK-3 also regulates the proteasomal degradation through $\beta$-catenin (Fig. 2) and it has been shown that both typical and atypical antipsychotics induce alterations in the expression of $\beta$ catenin and GSK-3 in the striatum and prefrontal cortex [201]. Recently $D_{3}$ Rs have been involved in the inactivation of GSK-3 $\beta$ through Akt (Fig. 2), however in the best of our knowledge there is no studies linking $\mathrm{D}_{3} \mathrm{Rs}$ in HD related with this signaling pathway.

Abnormalities in DA system might underlie some of the behavioral symptoms in HD, as a matter of fact HD patients treated with D2Rs agonist prevented the chorea but not the cognition impairments [202], as mentioned before hyperdopaminergic tone has been shown in early stages of HD, and TZB alleviates motor deficits as well as antagonist of D1Rs were able to prevent MSNs dead in a HD mouse model [203].

The development of novel and selective DA receptors compounds open a new field of study in HD, probably other potential therapies to treat motor alterations and psychiatric conditions in $\mathrm{HD}$, as well modulate the aggregates of $h t t$ as previously showed. Further studies are needed to fully understand the role of the specific DA receptors subtypes in HD, which might lead to novel therapeutic approaches.

\section{Multiple Sclerosis and DA receptors.}

MS is a complex disease that affects the brain and spinal cord, resulting in loss of muscle control, vision, balance, and sensation of numbness. In MS, the brain and spinal cord are damaged by the immune system, reason why this condition is called an autoimmune disease. MS is characterized by inflammation, demyelination and neurodegeneration, causes disability in both young and older populations.

Several autoimmune processes are mediated by myelin-specific $\mathrm{CD}^{+} \mathrm{T}$ helper $(\mathrm{Th})$, which are cells capable to cross the blood-brain barrier and cause damage [204]. It's been known that Th contributes to MS secreting pro-inflammatory cytokines, such as TNF $\alpha$ and IFN- $\gamma$ [205]. In addition, disruption of the blood-brain barrier allows the entry of B cells and T-cell dependent B cell activation results in neural damage [206].

DA and generally all catecholamines has been involved with MS. However recently, growing evidences shown that DA receptors are closely related with immune system and abnormalities of DA receptors and their function may participate in MS. In fact DA levels are increased in striatum [207].

The role of DARs has been also studied, decreased $\mathrm{D}_{5} \mathrm{Rs}$ could be related with the onset of MS, in peripheral blood mononuclear cells $\mathrm{D}_{5} \mathrm{Rs}$ was found to be decreased in non-treated MS patients [208], while in treated patients with (IFN)- $\gamma, \mathrm{D}_{5} \mathrm{Rs}$ were found increased. Interestingly the treatment with (IFN)- $\gamma$ induced enhanced tyrosine hydroxylase (TH) expression too and DA synthesis [209]. Furthermore dendritic cells, which are antigen-presenting cells, also synthesize DA that is released in autocrine manner and can stimulate $\mathrm{D}_{5} \mathrm{Rs}$ inducing production of IL-23, which causes polarization of $\mathrm{CD}^{+} \mathrm{T}$ cells toward the inflammatory phenotype [134]. DA increases production of TNFa via $D_{1}, D_{5}$ and $D_{3} R s$ and the production of IL-10 through $\mathrm{D}_{2}, \mathrm{D}_{1}$ and $\mathrm{D}_{5}$ Rs [135]. The role of DA and their receptors still unclear but several studies has shown that the changes in DA function and DA release are co-related with inflammation in autoimmune diseases. DA exhibits different affinities for the five DA receptors, showing higher affinity for $\mathrm{D}_{3}, \mathrm{D}_{4}$ and $\mathrm{D}_{5}$ Rs and lower $\mathrm{D}_{2}$ and $\mathrm{D}_{1} \mathrm{Rs}$ [210]. When lower levels of DA are released likely the main activation is $\mathrm{D}_{3} \mathrm{Rs}$ in $\mathrm{T}$ cells, which could lead to $\mathrm{T}$ cell migration, while higher levels of DA could activate $\mathrm{D}_{5} \mathrm{Rs}$ instead and as a consequence inhibition of the T cell function [129]. Despite the potential role of DA in MS, a pilot study in MS patients treated with D2Rs agonist after a year of treatment no changes were observed in the progression of this disease [211]. It's important to mention that other catecholamines are also participating such as $\beta$-adrenergic receptors (AR) and balance between $\mathrm{DA}$ and $\beta$-AR inhibitory and stimulatory effects play an important role in the lymphocytes activation. As the matter of fact in MS patients the dysregulation of $\beta$-AR and DA receptors might alter the balance of these catecholamines inducing dysfunctional events in the lymphocytes [206].

Although in the clinical experience the DA compounds showed very limited therapeutic benefits the recent research points DA as a potential target due to the ample expression of DA receptors in the immune system [208]. The understanding of the role of DA receptors in immune system could lead to novel pharmacological 
strategies to modulate the immune response by dopamine in MS.

\section{Conclusion}

The DA neurotransmission system and DA receptors play an important role in neurotoxicity and neurodegeneration. DA receptors are susceptible to change under pathological conditions and rearrangements of intracellular signal pathways might occur that worsen the symptoms in aging diseases or neurodegenerative process. The better understanding of the changes that occur in the DA receptors and their functional responses during pathological conditions is crucial for the development of novel and efficacious therapeutic approaches in neurodegeneration, neurotoxicity and neuroinflammation.

\section{References}

[1] Ben-Jonathan N (1985). Dopamine: a prolactininhibiting hormone. Endocr Rev, 6:564-589.

[2] Jackson DM, Westlind-Danielsson A (1994). Dopamine receptors: molecular biology, biochemistry and behavioural aspects. Pharmacol Ther, 64:291-370.

[3] Forn J, Krueger BK, Greengard P (1974). Adenosine 3',5'-monophosphate content in rat caudate nucleus: demonstration of dopaminergic and adrenergic receptors. Science, 186:1118-1120.

[4] Arisawa M, Makino T, Izumi S, lizuka R (1983). Effect of prostaglandin $\mathrm{D} 2$ on gonadotropin release from rat anterior pituitary in vitro. Fertil Steril, 39:93-96.

[5] Greengard P, Allen PB, Nairn AC (1999). Beyond the dopamine receptor: the DARPP-32/protein phosphatase-1 cascade. Neuron, 23:435-447.

[6] Civelli O, Bunzow JR, Grandy DK (1993). Molecular diversity of the dopamine receptors. Annu Rev Pharmacol Toxicol, 33:281-307.

[7] Missale C, Nash SR, Robinson SW, Jaber M, Caron MG (1998). Dopamine receptors: from structure to function. Physiol Rev, 78:189-225.

[8] Wamsley JK, Gehlert DR, Filloux FM, Dawson TM (1989). Comparison of the distribution of D-1 and D-2 dopamine receptors in the rat brain. J Chem Neuroanat, 2:119-137.

[9] Savasta M, Dubois A, Scatton B (1986). Autoradiographic localization of D1 dopamine receptors in the rat brain with $[3 \mathrm{H}] \mathrm{SCH} 23390$. Brain Res, 375:291-301.

[10] Boyson SJ, McGonigle P, Molinoff PB (1986). Quantitative autoradiographic localization of the D1 and D2 subtypes of dopamine receptors in rat brain. $\mathbf{J}$ Neurosci, 6:3177-3188.

[11] Cadet JL, Jayanthi S, McCoy MT, Beauvais G, Cai NS (2010). Dopamine D1 receptors, regulation of gene expression in the brain, and neurodegeneration. CNS Neurol Disord Drug Targets, 9:526-538.
[12] Graybiel AM, Aosaki T, Flaherty AW, Kimura M (1994). The basal ganglia and adaptive motor control. Science, 265:1826-1831.

[13] Tesmer JJ, Sunahara RK, Gilman AG, Sprang SR (1997). Crystal structure of the catalytic domains of adenylyl cyclase in a complex with Gsalpha.GTPgammaS. Science, 278:1907-1916.

[14] Sunahara RK, Taussig R (2002). Isoforms of mammalian adenylyl cyclase: multiplicities of signaling. Mol Interv, 2:168-184.

[15] Kim C, Vigil D, Anand G, Taylor SS (2006). Structure and dynamics of PKA signaling proteins. Eur J Cell Biol, 85:651-654.

[16] Akimoto M, Selvaratnam R, McNicholl ET, Verma G, Taylor SS, Melacini G (2013). Signaling through dynamic linkers as revealed by PKA. Proc Natl Acad Sci USA, 110:14231-14236.

[17] Rajput PS, Kharmate G, Somvanshi RK, Kumar U (2009). Colocalization of dopamine receptor subtypes with dopamine and cAMP-regulated phosphoprotein (DARPP-32) in rat brain. Neurosci Res, 65:53-63.

[18] Nishi A, Snyder GL, Fienberg AA, Fisone G, Aperia A, Nairn AC, Greengard P (1999). Requirement for DARPP-32 in mediating effect of dopamine D2 receptor activation. Eur J Neurosci, 11:2589-2592.

[19] Bibb JA, Snyder GL, Nishi A, Yan Z, Meijer L, Fienberg AA, Tsai LH, Kwon YT, Girault JA, Czernik AJ, Huganir RL, Hemmings HC, Jr Nairn AC, Greengard P (1999). Phosphorylation of DARPP-32 by Cdk5 modulates dopamine signalling in neurons. Nature, 402:669-671.

[20] Undieh AS (2010). Pharmacology of signaling induced by dopamine $\mathrm{D}(1)$-like receptor activation. Pharmacol Ther, 128:37-60.

[21] Surmeier DJ, Bargas J, Hemmings HC Jr, Nairn AC, Greengard P (1995). Modulation of calcium currents by a D1 dopaminergic protein kinase/phosphatase cascade in rat neostriatal neurons. Neuron, 14:385-397.

[22] Schiffmann SN, Desdouits F, Menu R, Greengard P, Vincent JD, Vanderhaeghen JJ, Girault JA (1998). Modulation of the voltage-gated sodium current in rat striatal neurons by DARPP-32, an inhibitor of protein phosphatase. Eur J Neurosci, 10:1312-1320.

[23] Roche KW, O'Brien RJ, Mammen AL, Bernhardt J, Huganir RL (1996). Characterization of multiple phosphorylation sites on the AMPA receptor GluR1 subunit. Neuron, 16:1179-1188.

[24] Hernandez-Lopez S, Tkatch T, Perez-Garci E, Galarraga E, Bargas J, Hamm H, Surmeier DJ (2000). D2 dopamine receptors in striatal medium spiny neurons reduce L-type Ca2+ currents and excitability via a novel PLC[beta]1-IP3-calcineurin-signaling cascade. J Neurosci, 20:8987-8995.

[25] Santini E, Valjent E, Usiello A, Carta M, Borgkvist A, Girault JA, Herve D, Greengard P, Fisone G (2007). Critical involvement of cAMP/DARPP-32 and extracellular signal-regulated protein kinase signaling in L-DOPA-induced dyskinesia. J Neurosci, 27:69957005 . 
[26] Altschuler DL, Peterson SN, Ostrowski MC, Lapetina EG (1995). Cyclic AMP-dependent activation of Rap1b. J Biol Chem, 270:10373-10376.

[27] Kawasaki H, Springett GM, Mochizuki N, Toki S, Nakaya M, Matsuda M, Housman DE, Graybiel AM (1998). A family of cAMP-binding proteins that directly activate Rap1. Science, 282:2275-2279.

[28] Bos JL, de Rooij J, Reedquist KA (2001). Rap1 signalling: adhering to new models. Nat Rev Mol Cell Biol, 2:369-377.

[29] Neves SR, Ram PT, Iyengar R (2002). G protein pathways. Science, 296:1636-1639.

[30] Lezcano N, Mrzljak L, Eubanks S, Levenson R, Goldman-Rakic P, Bergson C (2000). Dual signaling regulated by calcyon, a D1 dopamine receptor interacting protein. Science, 287:1660-1664.

[31] Ha CM, Park D, Han JK, Jang JI, Park JY, Hwang EM, Seok H, Chang S (2012). Calcyon forms a novel ternary complex with dopamine D1 receptor through PSD-95 protein and plays a role in dopamine receptor internalization. J Biol Chem, 287:31813-31822.

[32] Loos M, Pattij T, Janssen MC, Counotte DS, Schoffelmeer AN, Smit AB, Spijker S, van Gaalen MM (2010). Dopamine receptor D1/D5 gene expression in the medial prefrontal cortex predicts impulsive choice in rats. Cereb Cortex, 20:1064-1070.

[33] Koh PO, Bergson C, Undie AS, Goldman-Rakic PS, Lidow MS (2003). Up-regulation of the D1 dopamine receptor-interacting protein, calcyon, in patients with schizophrenia. Arch Gen Psychiatry, 60:311-319.

[34] Nishi A, Fisone G, Snyder GL, Dulubova I, Aperia A, Nairn AC, Greengard P (1999). Regulation of Na+, K+ATPase isoforms in rat neostriatum by dopamine and protein kinase C. J Neurochem, 73:1492-1501.

[35] Gomes P, Soares-da-Silva P (2002). Na(+)/H(+) exchanger activity and dopamine $\mathrm{D}(1)$-like receptor function in two opossum kidney cell clonal sublines. Cell Physiol Biochem, 12:259-268.

[36] Arnaldo FB, Villar VA, Konkalmatt PR, Owens SA, Asico LD, Jones JE, Yang J, Lovett DL, Armando I, Jose PA, Concepcion GP (2014). D1-like dopamine receptors downregulate $\mathrm{Na}+\mathrm{K}+-\mathrm{ATPase}$ activity and increase cAMP production in the posterior gills of the blue crab Callinectes sapidus. Am J Physiol Regul Integr Comp Physiol, 307:R634-42.

[37] Kebabian JW, Greengard P (1971). Dopamine-sensitive adenyl cyclase: possible role in synaptic transmission. Science, 174:1346-1349.

[38] Nishi A, Snyder GL, Nairn AC, Greengard P (1999). Role of calcineurin and protein phosphatase-2A in the regulation of DARPP-32 dephosphorylation in neostriatal neurons. J Neurochem, 72:2015-2021.

[39] Chio CL, Lajiness ME, Huff RM (1994). Activation of heterologously expressed D3 dopamine receptors: comparison with D2 dopamine receptors. Mol Pharmacol, 45:51-60.

[40] MacKenzie RG, VanLeeuwen D, Pugsley TA, Shih YH, Demattos S, Tang L, Todd RD, O'Malley KL (1994). Characterization of the human dopamine D3 receptor expressed in transfected cell lines. Eur J Pharmacol, 266:79-85.

[41] Zaworski PG, Alberts GL, Pregenzer JF, Im WB, Slightom JL, Gill GS (1999). Efficient functional coupling of the human D3 dopamine receptor to $G(0)$ subtype of $\mathrm{G}$ proteins in SH-SY5Y cells. $\mathrm{Br} \mathrm{J}$ Pharmacol, 128:1181-1188.

[42] Robinson SW, Caron MG (1997). Selective inhibition of adenylyl cyclase type $\mathrm{V}$ by the dopamine D3 receptor. Mol Pharmacol, 52:508-514.

[43] Cooper DM, Mons N, Karpen JW (1995). Adenylyl cyclases and the interaction between calcium and cAMP signalling. Nature, 374:421-424.

[44] Cooper DM (2003). Regulation and organization of adenylyl cyclases and cAMP. Biochem J, 375:517-529.

[45] Watts VJ (2002). Molecular mechanisms for heterologous sensitization of adenylate cyclase. J Pharmacol Exp Ther, 302:1-7.

[46] Krishnan V, Graham A, Mazei-Robison MS, Lagace DC, Kim KS, Birnbaum S, Eisch AJ, Han PL, Storm DR, Zachariou V, Nestler EJ (2008). Calcium-sensitive adenylyl cyclases in depression and anxiety: behavioral and biochemical consequences of isoform targeting. Biol Psychiatry, 64:336-343.

[47] Rangel-Barajas C, Silva I, Lopez-Santiago LM, Aceves J, Erlij D, Floran B (2011). L-DOPA-induced dyskinesia in hemiparkinsonian rats is associated with up-regulation of adenylyl cyclase type V/VI and increased GABA release in the substantia nigra reticulata. Neurobiol Dis, 41:51-61.

[48] Mark MD, Herlitze S (2000). G-protein mediated gating of inward-rectifier K+ channels. Eur J Biochem, 267:5830-5836.

[49] Pillai G, Brown NA, McAllister G, Milligan G, Seabrook GR (1998). Human D2 and D4 dopamine receptors couple through betagamma G-protein subunits to inwardly rectifying $\mathrm{K}+$ channels (GIRK1) in a Xenopus oocyte expression system: selective antagonism by L-741,626 and L-745,870 respectively. Neuropharmacology, 37:983-987.

[50] Davila V, Yan Z, Craciun LC, Logothetis D, Sulzer D (2003). D3 dopamine autoreceptors do not activate Gprotein-gated inwardly rectifying potassium channel currents in substantia nigra dopamine neurons. J Neurosci, 23:5693-5697.

[51] Beom S, Cheong D, Torres G, Caron MG, Kim KM (2004). Comparative studies of molecular mechanisms of dopamine D2 and D3 receptors for the activation of extracellular signal-regulated kinase. J Biol Chem, 279:28304-28314.

[52] Luedtke RR, Mishra Y, Wang Q, Griffin SA, BellHorner C, Taylor M, Vangveravong S, Dillon GH, Huang RQ, Reichert DE, Mach RH (2012). Comparison $o$ the binding and functional properties of two structurally different D2 dopamine receptor subtype selective compounds. ACS Chem Neurosci, 3:10501062.

[53] Lefkowitz RJ, Shenoy SK (2005). Transduction of receptor signals by beta-arrestins. Science, 308:512517. 
[54] Jin M, Min C, Zheng M, Cho DI, Cheong SJ, Kurose H, Kim KM (2013). Multiple signaling routes involved in the regulation of adenylyl cyclase and extracellular regulated kinase by dopamine $\mathrm{D}(2)$ and $\mathrm{D}(3)$ receptors. Pharmacol Res, 67:31-41.

[55] Gonzalez S, Rangel-Barajas C, Peper M, Lorenzo R, Moreno E, Ciruela F, Borycz J, Ortiz J, Lluis C, Franco R, McCormick PJ, Volkow ND, Rubinstein M, Floran B, Ferre S (2012). Dopamine D4 receptor, but not the ADHD-associated D4.7 variant, forms functional heteromers with the dopamine $\mathrm{D} 2 \mathrm{~S}$ receptor in the brain. Mol Psychiatry, 17:650-662.

[56] Brami-Cherrier K, Valjent E, Garcia M, Pages C, Hipskind RA, Caboche J (2002). Dopamine induces a PI3-kinase-independent activation of Akt in striatal neurons: a new route to cAMP response elementbinding protein phosphorylation. J Neurosci, 22:89118921.

[57] Mannoury la Cour C, Salles MJ, Pasteau V, Millan MJ (2011). Signaling pathways leading to phosphorylation of Akt and GSK-3beta by activation of cloned human and rat cerebral $\mathrm{D}(2)$ and $\mathrm{D}(3)$ receptors. Mol Pharmacol, 79:91-105.

[58] Beaulieu JM, Tirotta E, Sotnikova TD, Masri B, Salahpour A, Gainetdinov RR, Borrelli E, Caron MG (2007). Regulation of Akt signaling by D2 and D3 dopamine receptors in vivo. J Neurosci, 27:881-885.

[59] Collo G, Zanetti S, Missale C, Spano P (2008). Dopamine D3 receptor-preferring agonists increase dendrite arborization of mesencephalic dopaminergic neurons via extracellular signal-regulated kinase phosphorylation. Eur J Neurosci, 28:1231-1240.

[60] Collo G, Bono F, Cavalleri L, Plebani L, Merlo Pich E, Millan MJ, Spano PF, Missale C (2012). Pre-synaptic dopamine $\mathrm{D}(3)$ receptor mediates cocaine-induced structural plasticity in mesencephalic dopaminergic neurons via ERK and Akt pathways. J Neurochem, 120:765-778.

[61] Hoeffer CA, Klann E (2010). mTOR signaling: at the crossroads of plasticity, memory and disease. Trends Neurosci, 33:67-75.

[62] Peineau S, Bradley C, Taghibiglou C, Doherty A, Bortolotto ZA, Wang YT, Collingridge GL (2008). The role of GSK-3 in synaptic plasticity. Br J Pharmacol 153 Suppl 1:S428-37.

[63] Doble BW, Woodgett JR (2003). GSK-3: tricks of the trade for a multi-tasking kinase. J Cell Sci, 116:11751186.

[64] Emamian ES (2012). AKT/GSK3 signaling pathway and schizophrenia. Front Mol Neurosci, 15:5-33.

[65] Salles MJ, Herve D, Rivet JM, Longueville S, Millan MJ, Girault JA, Mannoury la CourC (2013). Transient and rapid activation of Akt/GSK-3beta and mTORC1 signaling by D3 dopamine receptor stimulation in dorsal striatum and nucleus accumbens. J Neurochem, 125:532-544.

[66] Rosenberg PA (1988). Catecholamine toxicity in cerebral cortex in dissociated cell culture. J Neurosci, 8:2887-2894.
[67] Tanaka M, Sotomatsu A, Kanai H, Hirai S (1991). Dopa and dopamine cause cultured neuronal death in the presence of iron. J Neurol Sci, 101:198-203.

[68] Hoyt KR, Reynolds IJ, Hastings TG (1997). Mechanisms of dopamine-induced cell death in cultured rat forebrain neurons: interactions with and differences from glutamate-induced cell death. Exp Neurol, 143:269-281.

[69] Ben-Shachar D, Zuk R, Gazawi H, Ljubuncic P (2004). Dopamine toxicity involves mitochondrial complex I inhibition: implications to dopamine-related neuropsychiatric disorders. Biochem Pharmacol, 67:1965-1974.

[70] Cheng N, Maeda T, Kume T, Kaneko S, Kochiyama H, Akaike A, Goshima Y, Misu Y (1996). Differential neurotoxicity induced by L-DOPA and dopamine in cultured striatal neurons. Brain Res, 743:278-283.

[71] Luo Y, Umegaki H, Wang X, Abe R, Roth GS (1998). Dopamine induces apoptosis through an oxidationinvolved SAPK/JNK activation pathway. J Biol Chem, 273:3756-3764.

[72] Di Filippo M, Picconi B, Costa C, Bagetta V, Tantucci M, Parnetti L, Calabresi P (2006). Pathways of neurodegeneration and experimental models of basal ganglia disorders: downstream effects of mitochondrial inhibition. Eur J Pharmacol, 545:65-72.

[73] Cadet J, D'Ham C, Douki T, Pouget JP, Ravanat JL, Sauvaigo S (1998). Facts and artifacts in the measurement of oxidative base damage to DNA. Free Radic Res, 29:541-550.

[74] Blum D, Torch S, Lambeng N, Nissou M, Benabid AL, Sadoul R, Verna JM (2001). Molecular pathways involved in the neurotoxicity of 6-OHDA, dopamine and MPTP: contribution to the apoptotic theory in Parkinson's disease. Prog Neurobiol, 65:135-172.

[75] Wersinger C, Chen J, Sidhu A (2004). Bimodal induction of dopamine-mediated striatal neurotoxicity is mediated through both activation of D1 dopamine receptors and autoxidation. Mol Cell Neurosci, 25:124137.

[76] Labandeira-Garcia JL, Rodriguez-Pallares J, Dominguez-Meijide A, Valenzuela R, Villar-Cheda B, Rodriguez-Perez AI (2013). Dopamine-angiotensin interactions in the basal ganglia and their relevance for Parkinson's disease. Mov Disord, 28:1337-1342.

[77] Li D, Scott L, Crambert S, Zelenin S, Eklof AC, Di Ciano L, Ibarra F, Aperia A (2012). Binding of losartan to angiotensin AT1 receptors increases dopamine D1 receptor activation. J Am Soc Nephrol, 23:421-428.

[78] Merchant KM, Letter AA, Gibb JW, Hanson GR (1988). Changes in the limbic neurotensin systems induced by dopaminergic drugs. Eur J Pharmacol, 153:1-9.

[79] Labandeira-Garcia JL, Rodriguez-Pallares J, VillarCheda B, Rodriguez-Perez AI, Garrido-Gil P, Guerra MJ (2011). Aging, Angiotensin system and dopaminergic degeneration in the substantia nigra. Aging Dis, 2:257-274.

[80] Labandeira-Garcia JL, Garrido-Gil P, RodriguezPallares J, Valenzuela R, Borrajo A, Rodriguez-Perez 
AI (2014). Brain renin-angiotensin system and dopaminergic cell vulnerability. Front Neuroanat 8:867.

[81] Chabrashvili T, Kitiyakara C, Blau J, Karber A, Aslam S, Welch WJ, Wilcox CS (2003). Effects of ANG II type 1 and 2 receptors on oxidative stress, renal NADPH oxidase, and SOD expression. Am J Physiol Regul Integr Comp Physiol, 285:R117-24.

[82] Jones ES, Vinh A, McCarthy CA, Gaspari TA, Widdop RE (2008). AT2 receptors: functional relevance in cardiovascular disease. Pharmacol Ther, 120:292-316.

[83] Vazquez E, Coronel I, Bautista R, Romo E, Villalon CM, Avila-Casado MC, Soto V, Escalante B (2005). Angiotensin II-dependent induction of AT(2) receptor expression after renal ablation. Am J Physiol Renal Physiol, 288:F207-13.

[84] Kehoe PG, Wilcock GK (2007). Is inhibition of the renin-angiotensin system a new treatment option for Alzheimer's disease?. Lancet Neurol, 6:373-378.

[85] Stegbauer J, Lee DH, Seubert S, Ellrichmann G, Manzel A, Kvakan H, Muller DN, Gaupp S, Rump LC, Gold R, Linker RA (2009). Role of the reninangiotensin system in autoimmune inflammation of the central nervous system. Proc Natl Acad Sci USA, 106:14942-14947.

[86] Labandeira-Garcia JL, Rodriguez-Pallares J, Rodriguez-Perez AI, Garrido-Gil P, Villar-Cheda B, Valenzuela R, Guerra MJ (2012). Brain angiotensin and dopaminergic degeneration: relevance to Parkinson's disease. Am J Neurodegener Dis, 1:226-244.

[87] Kerr DS, Bevilaqua LR, Bonini JS, Rossato JI, Kohler CA, Medina JH, Izquierdo I, Cammarota M (2005). Angiotensin II blocks memory consolidation through an AT2 receptor-dependent mechanism. Psychopharmacology (Berl), 179:529-535.

[88] Hermann K, McDonald W, Unger T, Lang RE, Ganten D (1984). Angiotensin biosynthesis and concentrations in brain of normotensive and hypertensive rats. J Physiol (Paris), 79:471-480.

[89] Stornetta RL, Hawelu-Johnson CL, Guyenet PG, Lynch KR (1988). Astrocytes synthesize angiotensinogen in brain. Science, 242:1444-1446

[90] Kumar A, Rassoli A, Raizada MK (1988). Angiotensinogen gene expression in neuronal and glial cells in primary cultures of rat brain. J Neurosci Res, 19:287-290.

[91] Noh KM, Koh JY (2000). Induction and activation by zinc of NADPH oxidase in cultured cortical neurons and astrocytes. J Neurosci, 20:RC111.

[92] Gao HM, Liu B, Zhang W, Hong JS (2003). Critical role of microglial NADPH oxidase-derived free radicals in the in vitro MPTP model of Parkinson's disease. FASEB J, 17:1954-1956.

[93] Wu DC, Teismann P, Tieu K, Vila M, Jackson-Lewis V, Ischiropoulos H, Przedborski S (2003). NADPH oxidase mediates oxidative stress in the 1-methyl-4phenyl-1,2,3,6-tetrahydropyridine model of Parkinson's disease. Proc Natl Acad Sci USA, 100:6145-6150.

[94] Rodriguez-Pallares J, Parga JA, Munoz A, Rey P, Guerra MJ, Labandeira-Garcia JL (2007). Mechanism of 6-hydroxydopamine neurotoxicity: the role of NADPH oxidase and microglial activation in 6hydroxydopamine-induced degeneration of dopaminergic neurons. J Neurochem, 103:145-156.

[95] Rodriguez-Pallares J, Rey P, Parga JA, Munoz A, Guerra MJ, Labandeira-Garcia JL (2008). Brain angiotensin enhances dopaminergic cell death via microglial activation and NADPH-derived ROS. Neurobiol Dis, 31:58-73.

[96] Joglar B, Rodriguez-Pallares J, Rodriguez-Perez AI, Rey P, Guerra MJ, Labandeira-Garcia JL (2009). The inflammatory response in the MPTP model of Parkinson's disease is mediated by brain angiotensin: relevance to progression of the disease. J Neurochem, 109:656-669.

[97] Babior BM (2004). NADPH oxidase. Curr Opin Immunol, 16:42-47.

[98] Rey P, Lopez-Real A, Sanchez-Iglesias S, Munoz A, Soto-Otero R, Labandeira-Garcia JL (2007). Angiotensin type-1-receptor antagonists reduce 6hydroxydopamine toxicity for dopaminergic neurons. Neurobiol Aging, 28:555-567.

[99] Villar-Cheda B, Dominguez-Meijide A, Valenzuela R, Granado N, Moratalla R, Labandeira-Garcia JL (2014). Aging-related dysregulation of dopamine and angiotensin receptor interaction. Neurobiol Aging, 35:1726-1738.

[100] Quinlan JT, Phillips MI (1981). Immunoreactivity for an angiotensin II-like peptide in the human brain. Brain Res, 205:212-218.

[101] Simonnet G, Giorguieff-Chesselet MF, Carayon A, Bioulac B, Cesselin F, Glowinski J, Vincent JD (1981). Angiotensin II and nigostriatal system (author's transl). J Physiol (Paris), 77:71-79.

[102] Brownfield MS, Reid IA, Ganten D, Ganong WF (1982). Differential distribution of immunoreactive angiotensin and angiotensin-converting enzyme in rat brain. Neuroscience, 7:1759-1769.

[103] Chai SY, Mendelsohn FA, Paxinos G (1987). Angiotensin converting enzyme in rat brain visualized by quantitative in vitro autoradiography. Neuroscience, 20:615-627.

[104] Rodriguez-Pallares J, Quiroz CR, Parga JA, Guerra MJ, Labandeira-Garcia JL (2004). Angiotensin II increases differentiation of dopaminergic neurons from mesencephalic precursors via angiotensin type 2 receptors. Eur J Neurosci, 20:1489-1498.

[105] Garrido-Gil P, Valenzuela R, Villar-Cheda B, Lanciego JL, Labandeira-Garcia JL (2013). Expression of angiotensinogen and receptors for angiotensin and prorenin in the monkey and human substantia nigra: an intracellular renin-angiotensin system in the nigra. Brain Struct Funct, 218:373-388.

[106] Mendelsohn FA, Jenkins TA, Berkovic SF (1993). Effects of angiotensin II on dopamine and serotonin turnover in the striatum of conscious rats. Brain Res, 613:221-229.

[107] Gildea JJ (2009). Dopamine and angiotensin as renal counterregulatory systems controlling sodium balance. Curr Opin Nephrol Hypertens, 18:28-32. 
[108] Li H, Armando I, Yu P, Escano C, Mueller SC, Asico L, Pascua A, Lu Q, Wang X, Villar VA, Jones JE, Wang Z, Periasamy A, Lau YS, Soares-da-Silva P, Creswell K, Guillemette G, Sibley DR, Eisner G, Gildea JJ, Felder RA, Jose PA (2008). Dopamine 5 receptor mediates ang II type 1 receptor degradation via a ubiquitin-proteasome pathway in mice and human cells. J Clin Invest, 118:2180-2189.

[109] Zeng C, Asico LD, Wang X, Hopfer U, Eisner GM, Felder RA, Jose PA (2003). Angiotensin II regulation of AT1 and D3 dopamine receptors in renal proximal tubule cells of SHR. Hypertension, 41:724-729.

[110] Grammatopoulos TN, Jones SM, Ahmadi FA, Hoover BR, Snell LD, Skoch J, Jhaveri V V, Poczobutt AM, Weyhenmeyer JA, Zawada WM (2007). Angiotensin type 1 receptor antagonist losartan, reduces MPTPinduced degeneration of dopaminergic neurons in substantia nigra. Mol Neurodegener, 2:1-17.

[111] Zawada WM, Banninger GP, Thornton J, Marriott B, Cantu D, Rachubinski AL, Das M, Griffin WS, Jones SM (2011). Generation of reactive oxygen species in 1methyl-4-phenylpyridinium (MPP+) treated dopaminergic neurons occurs as an NADPH oxidasedependent two-wave cascade. J Neuroinflammation, 129:1-13

[112] Sonsalla PK, Coleman C, Wong LY, Harris SL, Richardson JR, Gadad BS, Li W, German DC (2013). The angiotensin converting enzyme inhibitor captopril protects nigrostriatal dopamine neurons in animal models of parkinsonism. Exp Neurol, 250:376-383.

[113] Lopez-Real A, Rey P, Soto-Otero R, Mendez-Alvarez E, Labandeira-Garcia JL (2005). Angiotensinconverting enzyme inhibition reduces oxidative stress and protects dopaminergic neurons in a 6hydroxydopamine rat model of Parkinsonism. J Neurosci Res 81:865-873.

[114] Muñoz A, Rey P, Guerra MJ, Mendez-Alvarez E, SotoOtero R, Labandeira-Garcia JL (2006). Reduction of dopaminergic degeneration and oxidative stress by inhibition of angiotensin converting enzyme in a MPTP model of parkinsonism. Neuropharmacology, 51:112120.

[115] Sanchez-Iglesias S, Rey P, Mendez-Alvarez E, Labandeira-Garcia JL, Soto-Otero R (2007). Timecourse of brain oxidative damage caused by intrastriatal administration of 6-hydroxydopamine in a rat model of Parkinson's disease. Neurochem Res, 32:99-105.

[116] Dominguez-Meijide A, Villar-Cheda B, Garrido-Gil P, Sierrra-Paredes G, Guerra MJ, Labandeira-Garcia JL (2014). Effect of chronic treatment with angiotensin type 1 receptor antagonists on striatal dopamine levels in normal rats and in a rat model of Parkinson's disease treated with L-DOPA. Neuropharmacology, 76:156168.

[117] Brown DC, Steward LJ, Ge J, Barnes NM (1996). Ability of angiotensin II to modulate striatal dopamine release via the AT1 receptor in vitro and in vivo. Br J Pharmacol, 118:414-420.

[118] Muñoz A, Garrido-Gil P, Dominguez-Meijide A, Labandeira-Garcia JL (2014). Angiotensin type 1 receptor blockage reduces 1-dopa-induced dyskinesia in the 6-OHDA model of Parkinson's disease. Involvement of vascular endothelial growth factor and interleukin-1beta. Exp Neurol 261C:720-732.

[119] Hussain T, Abdul-Wahab R, Kotak DK, Lokhandwala MF (1998). Bromocriptine regulates angiotensin II response on sodium pump in proximal tubules. Hypertension, 32:1054-1059.

[120] Zeng C, Luo Y, Asico LD, Hopfer U, Eisner GM, Felder RA, Jose PA (2003). Perturbation of D1 dopamine and AT1 receptor interaction in spontaneously hypertensive rats. Hypertension, 42:787792.

[121] Valenzuela R, Barroso-Chinea P, Villar-Cheda B, Joglar B, Munoz A, Lanciego JL, Labandeira-Garcia JL (2010). Location of prorenin receptors in primate substantia nigra: effects on dopaminergic cell death. J Neuropathol Exp Neurol, 69:1130-1142.

[122] Jenkins TA, Wong JY, Howells DW, Mendelsohn FA, Chai SY (1999). Effect of chronic angiotensinconverting enzyme inhibition on striatal dopamine content in the MPTP-treated mouse. J Neurochem, 73:214-219.

[123] Reardon KA, Mendelsohn FA, Chai SY, Horne MK (2000). The angiotensin converting enzyme (ACE) inhibitor, perindopril, modifies the clinical features of Parkinson's disease. Aust N Z J Med, 30:48-53.

[124] Ohshima K, Mogi M, Horiuchi M (2013). Therapeutic approach for neuronal disease by regulating reninangiotensin system. Curr Hypertens Rev, 9:99-107.

[125] Platten M, Youssef S, Hur EM, Ho PP, Han MH, Lanz TV, Phillips LK, Goldstein MJ, Bhat R, Raine CS, Sobel RA, Steinman L (2009). Blocking angiotensinconverting enzyme induces potent regulatory $\mathrm{T}$ cells and modulates TH1- and TH17-mediated autoimmunity. Proc Natl Acad Sci USA, 106:1494814953.

[126] Lanz TV, Ding Z, Ho PP, Luo J, Agrawal AN, Srinagesh H, Axtell R, Zhang H, Platten M, WyssCoray T, Steinman L (2010). Angiotensin II sustains brain inflammation in mice via TGF-beta. J Clin Invest, 120:2782-2794.

[127] Touyz RM (2004). Reactive oxygen species and angiotensin II signaling in vascular cells -- implications in cardiovascular disease. Braz J Med Biol Res, 37:1263-1273.

[128] Hoogwerf BJ (2010). Renin-angiotensin system blockade and cardiovascular and renal protection. Am J Cardiol, 105:30A-5A.

[129] Pacheco R, Prado CE, Barrientos MJ, Bernales S (2009). Role of dopamine in the physiology of T-cells and dendritic cells. J Neuroimmunol, 216:8-19.

[130] Bergquist J, Silberring J (1998). Identification of catecholamines in the immune system by electrospray ionization mass spectrometry. Rapid Commun Mass Spectrom, 12:683-688.

[131] Cosentino M, Zaffaroni M, Ferrari M, Marino F, Bombelli R, Rasini E, Frigo G, Ghezzi A, Comi G, Lecchini S (2005). Interferon-gamma and interferonbeta affect endogenous catecholamines in human 
peripheral blood mononuclear cells: implications for multiple sclerosis. J Neuroimmunol, 162:112-121.

[132] McKenna F, McLaughlin PJ, Lewis BJ, Sibbring GC, Cummerson JA, Bowen-Jones D, Moots RJ (2002). Dopamine receptor expression on human $\mathrm{T}$ - and $\mathrm{B}$ lymphocytes, monocytes, neutrophils, eosinophils and NK cells: a flow cytometric study. J Neuroimmunol, 132:34-40.

[133] Nakano K, Higashi T, Hashimoto K, Takagi R, Tanaka Y, Matsushita S (2008). Antagonizing dopamine D1like receptor inhibits Th17 cell differentiation: preventive and therapeutic effects on experimental autoimmune encephalomyelitis. Biochem Biophys Res Commun, 373:286-291.

[134] Prado C, Contreras F, Gonzalez H, Diaz P, Elgueta D, Barrientos M, Herrada AA, Lladser A, Bernales S, Pacheco R (2012). Stimulation of dopamine receptor D5 expressed on dendritic cells potentiates Th17mediated immunity. J Immunol 188:3062-3070.

[135] Besser MJ, Ganor Y, Levite M (2005). Dopamine by itself activates either D2, D3 or D1/D5 dopaminergic receptors in normal human $\mathrm{T}$-cells and triggers the selective secretion of either IL-10, TNFalpha or both. J Neuroimmunol, 169:161-171.

[136] Ilani T, Strous RD, Fuchs S (2004). Dopaminergic regulation of immune cells via D3 dopamine receptor: a pathway mediated by activated T cells. FASEB J, 18:1600-1602.

[137] Laman JD, Weller RO, (2013). Drainage of cells and soluble antigen from the CNS to regional lymph nodes. J Neuroimmune Pharmacol, 8:840-856.

[138] Radjavi A, Smirnov I, Kipnis J (2014). Brain antigenreactive CD4+ T cells are sufficient to support learning behavior in mice with limited $\mathrm{T}$ cell repertoire. Brain Behav Immun, 35:58-63.

[139] Gonzalez H, Contreras F. Prado C, Elgueta D, Franz D, Bernales S, Pacheco R (2013). Dopamine receptor D3 expressed on CD4+ T cells favors neurodegeneration of dopaminergic neurons during Parkinson's disease. J Immunol, 190:5048-5056.

[140] Penney JB Jr, Young AB (1983). Speculations on the functional anatomy of basal ganglia disorders. Annu Rev Neurosci, 6:73-94.

[141] Albin RL, Young AB, Penney JB (1989). The functional anatomy of basal ganglia disorders. Trends Neurosci, 12:366-375.

[142] Gerfen CR, Engber TM, Mahan LC, Susel Z, Chase TN, Monsma FJ,Jr, Sibley DR (1990). D1 and D2 dopamine receptor-regulated gene expression of striatonigral and striatopallidal neurons. Science, 250:1429-1432.

[143] Floran B, Aceves J, Sierra A, Martinez-Fong D (1990). Activation of D1 dopamine receptors stimulates the release of GABA in the basal ganglia of the rat. Neurosci Lett, 116:136-140.

[144] Floran B, Floran L, Sierra A, Aceves J (1997). D2 receptor-mediated inhibition of GABA release by endogenous dopamine in the rat globus pallidus. Neurosci Lett, 237:1-4.

[145] Cooper AJ, Stanford IM (2001). Dopamine D2 receptor mediated presynaptic inhibition of striatopallidal
GABA(A) IPSCs in vitro. Neuropharmacology, 41:6271.

[146] Obeso JA, Rodriguez-Oroz MC, Rodriguez M, Macias R, Alvarez L, Guridi J, Vitek J, DeLong MR (2000). Pathophysiologic basis of surgery for Parkinson's disease. Neurology, 55:S7-12.

[147] Napolitano M, Centonze D, Calce A, Picconi B, Spiezia S, Gulino A, Bernardi G, Calabresi P (2002). Experimental parkinsonism modulates multiple genes involved in the transduction of dopaminergic signals in the striatum. Neurobiol Dis, 10:387-395.

[148] Aubert I, Guigoni C, Hakansson K, Li Q, Dovero S, Barthe N, Bioulac BH, Gross CE, Fisone G, Bloch B, Bezard E (2005). Increased D1 dopamine receptor signaling in levodopa-induced dyskinesia. Ann Neurol, 57:17-26

[149] Silva I. Cortes H, Escartin E, Rangel C, Floran L, Erlij D, Aceves J, Floran B (2006). L-DOPA inhibits depolarization-induced $[3 \mathrm{H}] \mathrm{GABA}$ release in the dopamine-denervated globus pallidus of the rat: the effect is dopamine independent and mediated by D2like receptors. J Neural Transm, 113:1847-1853.

[150] Prieto GA, Perez-Burgos A, Fiordelisio T, Salgado H, Galarraga E, Drucker-Colin R, Bargas J (2009). Dopamine $\mathrm{D}(2)$-class receptor supersensitivity as reflected in $\mathrm{Ca} 2+$ current modulation in neostriatal neurons. Neuroscience, 164:345-350.

[151] Rangel-Barajas C, Silva I, Garcia-Ramirez M, SanchezLemus E, Floran L, Aceves J, Erlij D, Floran B (2008). 6-OHDA-induced hemiparkinsonism and chronic LDOPA treatment increase dopamine D1-stimulated $[(3) \mathrm{H}]-\mathrm{GABA}$ release and [(3)H]-cAMP production in substantia nigra pars reticulata of the rat. Neuropharmacology, 55:704-711.

[152] Cai G, Wang HY, Friedman E (2002). Increased dopamine receptor signaling and dopamine receptor- $\mathrm{G}$ protein coupling in denervated striatum. J Pharmacol Exp Ther, 302:1105-1112.

[153] Alexander GE, Crutcher MD (1990). Functional architecture of basal ganglia circuits: neural substrates of parallel processing. Trends Neurosci, 13:266-271.

[154] Feyder M, Bonito-Oliva A, Fisone G (2011). L-DOPAInduced Dyskinesia and Abnormal Signaling in Striatal Medium Spiny Neurons: Focus on Dopamine D1 Receptor-Mediated Transmission. Front Behav Neurosci, 5:1-10.

[155] Santini E, Feyder M, Gangarossa G, Bateup HS, Greengard P, Fisone G (2012). Dopamine- and cAMPregulated phosphoprotein of $32-\mathrm{kDa}$ (DARPP-32)dependent activation of extracellular signal-regulated kinase (ERK) and mammalian target of rapamycin complex 1 (mTORC1) signaling in experimental parkinsonism. J Biol Chem, 287:27806-27812.

[156] Park HY, Kang YM, Kang Y, Park TS, Ryu YK, Hwang JH, Kim YH, Chung BH, Nam KH, Kim MR, Lee CH, Han PL, Kim KS (2014). Inhibition of Adenylyl Cyclase Type 5 Prevents 1-DOPA-Induced Dyskinesia in an Animal Model of Parkinson's Disease. J Neurosci, 34:11744-11753. 
[157] Lee T, Seeman P, Rajput A, Farley IJ, Hornykiewicz O (1978). Receptor basis for dopaminergic supersensitivity in Parkinson's disease. Nature, 273:5961.

[158] Levey AI, Hersch SM, Rye DB, Sunahara RK, Niznik HB, Kitt CA, Price DL, Maggio R, Brann MR, Ciliax BJ (1993). Localization of D1 and D2 dopamine receptors in brain with subtype-specific antibodies. Proc Natl Acad Sci USA, 90:8861-8865.

[159] Levant B (1998). Differential distribution of D3 dopamine receptors in the brains of several mammalian species. Brain Res, 800:269-274.

[160] Prieto GA, Perez-Burgos A, Palomero-Rivero M, Galarraga E, Drucker-Colin R, Bargas J (2011). Upregulation of D2-class signaling in dopaminedenervated striatum is in part mediated by $\mathrm{D} 3$ receptors acting on $\mathrm{Ca}$ V 2.1 channels via PIP2 depletion. J Neurophysiol, 105:2260-2274.

[161] Cruz-Trujillo R, Avalos-Fuentes A, Rangel-Barajas C, Paz-Bermudez F, Sierra A, Escartin-Perez E, Aceves J, Erlij D, Floran B (2013). D3 dopamine receptors interact with dopamine D1 but not D4 receptors in the GABAergic terminals of the $\mathrm{SNr}$ of the rat. Neuropharmacology, 67:370-378.

[162] Avalos-Fuentes A, Loya-Lopez S, Flores-Perez A, Recillas-Morales S, Cortes H, Paz-Bermudez F, Aceves J, Erlij D, Floran B (2013). Presynaptic CaMKIIalpha modulates dopamine D3 receptor activation in striatonigral terminals of the rat brain in a $\mathrm{Ca}(2)(+)$ dependent manner. Neuropharmacology, 71:273-281.

[163] Bordet R, Ridray S, Carboni S, Diaz J, Sokoloff P, Schwartz JC (1997). Induction of dopamine D3 receptor expression as a mechanism of behavioral sensitization to levodopa. Proc Natl Acad Sci USA, 94:3363-3367.

[164] Sun J, Cairns NJ, Perlmutter JS, Mach RH, Xu J (2013). Regulation of dopamine D receptor in the striatal regions and substantia nigra in diffuse Lewy body disease. Neuroscience, 248C:112-126.

[165] Albarrán S, Ávalos-Fuentes A, Paz-Bermúdez F, Erlij D, Aceves J, Floran B (2013). Dopamine D3 receptor prevents $\mathrm{D} 1$ receptor stimulation of $[3 \mathrm{H}]$ GABA release in substantia nigra pars reticulata of hemiparkinsonian dyskinetic rats. Soc Neursc Abstr, 240.06/M7.

[166] Van Kampen JM, Robertson HA (2005). A possible role for dopamine D3 receptor stimulation in the induction of neurogenesis in the adult rat substantia nigra. Neuroscience, 136:381-386.

[167] Van Kampen JM, Eckman CB (2006). Dopamine D3 receptor agonist delivery to a model of Parkinson's disease restores the nigrostriatal pathway and improves locomotor behavior. J Neurosci, 26:7272-7280.

[168] Fiorentini C, Busi C, Spano P, Missale C (2008). Role of receptor heterodimers in the development of L-dopainduced dyskinesias in the 6-hydroxydopamine rat model of Parkinson's disease. Parkinsonism Relat Disord 14 Suppl, 2:S159-64.

[169] Marcellino D, Ferre S, Casado V, Cortes A, Le Foll B, Mazzola C, Drago F, Saur O, Stark H, Soriano A, Barnes C, Goldberg SR, Lluis C, Fuxe K, Franco R
(2008). Identification of dopamine D1-D3 receptor heteromers. Indications for a role of synergistic D1-D3 receptor interactions in the striatum. J Biol Chem, 283:26016-26025.

[170] Gutekunst CA, Li SH, Yi H, Mulroy JS, Kuemmerle S, Jones R, Rye D, Ferrante RJ, Hersch SM, Li XJ (1999). Nuclear and neuropil aggregates in Huntington's disease: relationship to neuropathology. J Neurosci, 19:2522-2534.

[171] Quarrell O, O'Donovan KL, Bandmann O, Strong M (2012). The Prevalence of Juvenile Huntington's Disease: A Review of the Literature and Meta-Analysis. PLoS Curr Hunt Dis, 20:1-11

[172] Vonsattel JP, Myers RH, Stevens TJ, Ferrante RJ, Bird ED, Richardson EP Jr (1985). Neuropathological classification of Huntington's disease. J Neuropathol Exp Neurol, 44:559-577.

[173] Deng YP, Albin RL, Penney JB, Young AB, Anderson KD, Reiner A (2004). Differential loss of striatal projection systems in Huntington's disease: a quantitative immunohistochemical study. J Chem Neuroanat, 27:143-164.

[174] Cowan CM, Fan MM, Fan J, Shehadeh J, Zhang LY, Graham RK, Hayden MR, Raymond LA (2008). Polyglutamine-modulated striatal calpain activity in YAC transgenic huntington disease mouse model: impact on NMDA receptor function and toxicity. $\mathbf{J}$ Neurosci, 28:12725-12735.

[175] Duncan GE, Inada K, Koller BH anMoy SS (2010). Increased sensitivity to kainic acid in a genetic model of reduced NMDA receptor function. Brain Res, 1307:166-176.

[176] Estrada-Sanchez AM, Montiel T, Segovia J, Massieu L (2009). Glutamate toxicity in the striatum of the R6/2 Huntington's disease transgenic mice is age-dependent and correlates with decreased levels of glutamate transporters. Neurobiol Dis, 34:78-86.

[177] Brito VI, Rozanski VE, Beyer C, Kuppers E (2009). Dopamine regulates the expression of the glutamate transporter GLT1 but not GLAST in developing striatal astrocytes. J Mol Neurosci, 39:372-379.

[178] Rotaru DC, Lewis DA, Gonzalez-Burgos G (2007). Dopamine D1 receptor activation regulates sodium channel-dependent EPSP amplification in rat prefrontal cortex pyramidal neurons. J Physiol, 581:981-1000.

[179] Bernheimer H, Birkmayer W, Hornykiewicz O, Jellinger K, Seitelberger F (1973). Brain dopamine and the syndromes of Parkinson and Huntington. Clinical, morphological and neurochemical correlations. J Neurol Sci, 20:415-455.

[180] Bedard C, Wallman MJ, Pourcher E, Gould PV, Parent A, Parent M (2011). Serotonin and dopamine striatal innervation in Parkinson's disease and Huntington's chorea. Parkinsonism Relat Disord, 17:593-598.

[181] Ginovart N, Lundin A, Farde L, Halldin C, Backman L, Swahn CG, Pauli S and Sedvall G (1997). PET study of the pre- and post-synaptic dopaminergic markers for the neurodegenerative process in Huntington's disease. Brain, 120(Pt 3):503-514. 
[182] Bohnen NI, Koeppe RA, Meyer P, Ficaro E, Wernette K. Kilbourn MR, Kuhl DE, Frey KA, Albin RL (2000). Decreased striatal monoaminergic terminals in Huntington disease. Neurology, 54:1753-1759.

[183] Garrett MC, Soares-da-Silva P (1992). Increased cerebrospinal fluid dopamine and 3,4dihydroxyphenylacetic acid levels in Huntington's disease: evidence for an overactive dopaminergic brain transmission. J Neurochem, 58:101-106.

[184] Suzuki T, Miura M, Nishimura K, Aosaki T (2001). Dopamine-dependent synaptic plasticity in the striatal cholinergic interneurons. J Neurosci, 21:6492-6501.

[185] Richfield EK, O'Brien CF, Eskin T, Shoulson I (1991). Heterogeneous dopamine receptor changes in early and late Huntington's disease. Neurosci Lett, 132:121-126.

[186] Ariano MA, Aronin N, Difiglia M, Tagle DA, Sibley DR, Leavitt BR, Hayden MR, Levine MS (2002). Striatal neurochemical changes in transgenic models of Huntington's disease. J Neurosci Res, 68:716-729.

[187] Van Oostrom JC, Dekker M, Willemsen AT, de Jong BM, Roos RA, Leenders KL (2009). Changes in striatal dopamine D2 receptor binding in pre-clinical Huntington's disease. Eur J Neurol, 16:226-231.

[188] Backman L, Farde L (2001). Dopamine and cognitive functioning: brain imaging findings in Huntington's disease and normal aging. Scand J Psychol, 42:287-296.

[189] Carter RJ, Lione LA, Humby T, Mangiarini L, Mahal A, Bates GP, Dunnett SB, Morton AJ (1999). Characterization of progressive motor deficits in mice transgenic for the human Huntington's disease mutation. J Neurosci, 19:3248-3257.

[190] Lione LA, Carter RJ, Hunt M J, Bates GP, Morton AJ, Dunnett SB (1999). Selective discrimination learning impairments in mice expressing the human Huntington's disease mutation. J Neurosci, 19:1042810437.

[191] Gerfen CR, Miyachi S, Paletzki R, Brown P (2002). D1 dopamine receptor supersensitivity in the dopaminedepleted striatum results from a switch in the regulation of ERK1/2/MAP kinase. J Neurosci, 22:5042-5054.

[192] Augood SJ, Faull RL, Emson PC (1997). Dopamine D1 and D2 receptor gene expression in the striatum in Huntington's disease. Ann Neurol 42:215-221.

[193] Cha JH, Kosinski CM, Kerner JA, Alsdorf SA, Mangiarini L, Davies SW, Penney JB, Bates GP, Young AB (1998). Altered brain neurotransmitter receptors in transgenic mice expressing a portion of an abnormal human huntington disease gene. Proc Natl Acad Sci USA, 95:6480-6485.

[194] Bibb JA, Yan Z, Svenningsson P, Snyder GL, Pieribone VA, Horiuchi A, Nairn AC, Messer A, Greengard P (2000). Severe deficiencies in dopamine signaling in presymptomatic Huntington's disease mice. Proc Natl Acad Sci USA, 97:6809-6814.

[195] Murphy-Nakhnikian A. Dorner JL, Fischer BI, BowerBir ND, Rebec GV (2012). Abnormal burst patterns of single neurons recorded in the substantia nigra reticulata of behaving $140 \mathrm{CAG}$ Huntington's disease mice. Neurosci Lett, 512:1-5.
[196] Sarkar S, Krishna G, Imarisio S, Saiki S, O'Kane CJ, Rubinsztein DC (2008). A rational mechanism for combination treatment of Huntington's disease using lithium and rapamycin. Hum Mol Genet, 17:170-178.

[197] Lim NK, Hung LW, Pang TY, Mclean CA, Liddell JR, Hilton JB, Li QX, White AR, Hannan AJ, Crouch PJ (2014). Localized changes to glycogen synthase kinase3 and collapsin response mediator protein-2 in the Huntington's disease affected brain. Hum Mol Gene, 23:4051-4063.

[198] Valencia A, Reeves PB, Sapp E, Li X, Alexander J, Kegel KB, Chase K. Aronin N, DiFiglia M (2010). Mutant huntingtin and glycogen synthase kinase 3-beta accumulate in neuronal lipid rafts of a presymptomatic knock-in mouse model of Huntington's disease. J Neurosci Res, 88:179-190.

[199] Beaulieu JM, Gainetdinov RR, Caron MG (2007). The Akt-GSK-3 signaling cascade in the actions of dopamine. Trends Pharmacol Sci, 28:166-172.

[200] Sutton LP, Rushlow WJ (2011). The effects of neuropsychiatric drugs on glycogen synthase kinase-3 signaling. Neuroscience, 199:116-124.

[201] Alimohamad H, Rajakumar N, Seah YH, Rushlow W (2005). Antipsychotics alter the protein expression levels of beta-catenin and GSK-3 in the rat medial prefrontal cortex and striatum. Biol Psychiatry, 57:533542.

[202] Brusa L, Orlacchio A, Moschella V, Iani C, Bernardi G, Mercuri NB (2009). Treatment of the symptoms of Huntington's disease: preliminary results comparing aripiprazole and tetrabenazine. Mov Disord, 24:126129.

[203] Tang TS, Chen X, Liu J, Bezprozvanny I (2007). Dopaminergic signaling and striatal neurodegeneration in Huntington's disease. J Neurosci, 27:7899-7910.

[204] Kasper LH, Shoemaker J (2010). Multiple sclerosis immunology: The healthy immune system vs the MS immune system. Neurology, 74:S2-8.

[205] Hemmer B, Nessler S, Zhou D, Kieseier B, Hartung HP (2006). Immunopathogenesis and immunotherapy of multiple sclerosis. Nat Clin Pract Neurol, 2:201-211.

[206] Cosentino M, Marino F (2013). Adrenergic and dopaminergic modulation of immunity in multiple sclerosis: teaching old drugs new tricks? J Neuroimmune Pharmacol, 8:163-179.

[207] Balkowiec-Iskra E, Kurkowska-Jastrzebska I, Joniec I, Ciesielska A, Czlonkowska A, Czlonkowski A (2007). Dopamine, serotonin and noradrenaline changes in the striatum of C57BL mice following myelin oligodendrocyte glycoprotein (MOG) 35-55 and complete Freund adjuvant (CFA) administration. Acta Neurobiol Exp (Wars), 67:379-388.

[208] Giorelli M, Livrea P, Trojano M (2005). Dopamine fails to regulate activation of peripheral blood lymphocytes from multiple sclerosis patients: effects of IFN-beta. J Interferon Cytokine Res, 25:395-406.

[209] Zaffaroni M, Marino F, Bombelli R, Rasini E, Monti M, Ferrari M, Ghezzi A, Comi G, Lecchini S, Cosentino M (2008). Therapy with interferon-beta modulates 
endogenous catecholamines in lymphocytes of patients with multiple sclerosis. Exp Neurol, 214:315-321.

[210] Seeman P, Van Tol HH (1994). Dopamine receptor pharmacology. Trends Pharmacol Sci, 15:264-270.

[211] Bissay V, De Klippel N, Herroelen L, Schmedding E, Buisseret T, Ebinger G, De Keyser J (1994).
Bromocriptine therapy in multiple sclerosis: an open label pilot study. Clin Neuropharmacol, 17:473-476. 